UM Libraries Depository

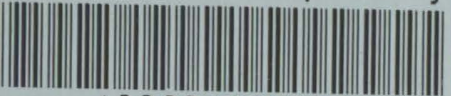
103284902004 


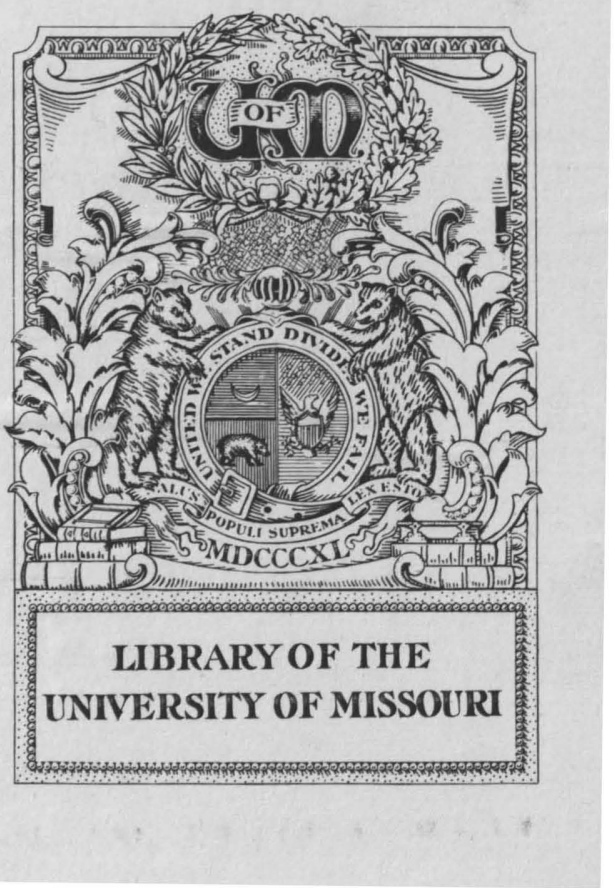






TO WHAT EXTENT DOES A STEER GROW DURING

THE PROCESS OF FATTENING

by

ARTHUR ANWYL JONES

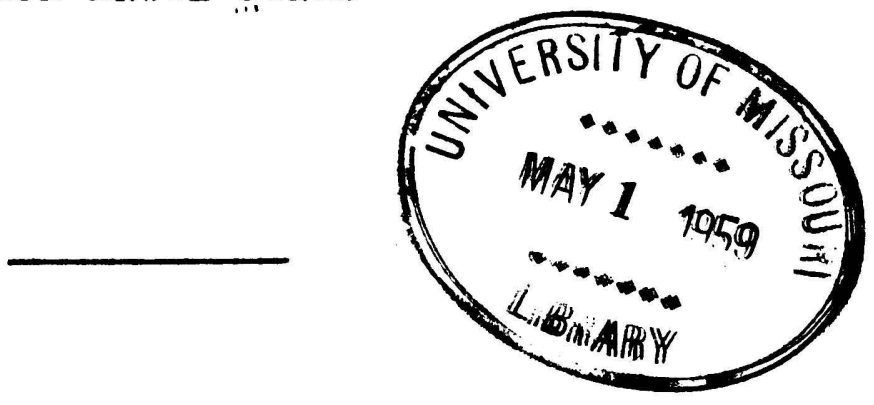

SUBMITTED IN PARTIAL FULFILLMENT OF THE

REQUIREMENTS FOR THE DEGREE OF

MASTER OF SCIMNCW

In the

$\because \because$

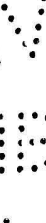

$\therefore \because \cdots$

GRADUATE DRPARTMENT

of the

COLLEGE OF AGRICULTURE

of the

UNIVERSITY OF MISSOURI

1910. 



\section{TO WHAT EXTENT DOES A STEER GROW DURING THE PROCESS OF FATTENING.}

From the stock feeders point of view the question of how much flesh can be put on a steer in a given length of time is all Important. Every pound of gain a steer makes means money to the feeder.

Durling the early life of a steer he grows very raplaly In all parts. The bones and muscles lengthen out and increase In size, the internal organs increase and from a birth-weight of less than one-hundred pounds, in twelve months the animal has Increased to several hundred pounds.

Th1s is but the result of nature and if properly fed and nourlshed to 1t's full capaolty the steer attains the full size heredity intended it to have. A beef steer is usually considered marketably mature when it 18 from two to three years old. The bones, muscles and organs are then approximately normally developed. After this however, the muscles may be Increased in size, fat may be deposited and a general filling out of the body take place when a sufflcient ration is fed. This extra increase then 1s termed fattening. The fattening or fintshing process is done for the demands of the market whioh require a well marbled meat. This can only be done by the extra fattening process, feeding the steer all he will eat for a length of time.

The amount of feed required during the growth of the animal in size 18 used for malntenance purposes and for growth. 

When the growth and malntenance requirements are satisfied the next use of the food $1 \mathrm{~s}$ to store up fat in varlous parts of the body for future needs. This fat may be stored up in many places. Fat may be layed on the outside of the muscles, between the muscles, in between the muscle flbers themselves, around the internal organs and in the skeleton.

With a steer which has had only enough feed to supply the maintenance requirement and that of growth we would expect to find little if any fat doposited in those various places. DESCRIPTION OF THE STEERS AND PLAN

OF THE EXPERIMENT.

Three steers, numbered 18, 121, and 48 were chosen from the group of regular maintenance steers, on an experiment at the University of Missourl to find out the uses to which an animal puts it's food.

These three steers were taken as being about the same age, two and a half to three years, and therefore were considered as mature as steers generally are when marketed. They were all treated alike previous to the time they were started on this experiment. From the first of February 1907, they were fed varying amounts of feed so that at the time they were all alike In condition and weight they could be started on the experiment. They were all grade Shorthorns and were good representatives of a poor feeding type. Since all three steers were very nearly mature, about the same type and breed and 



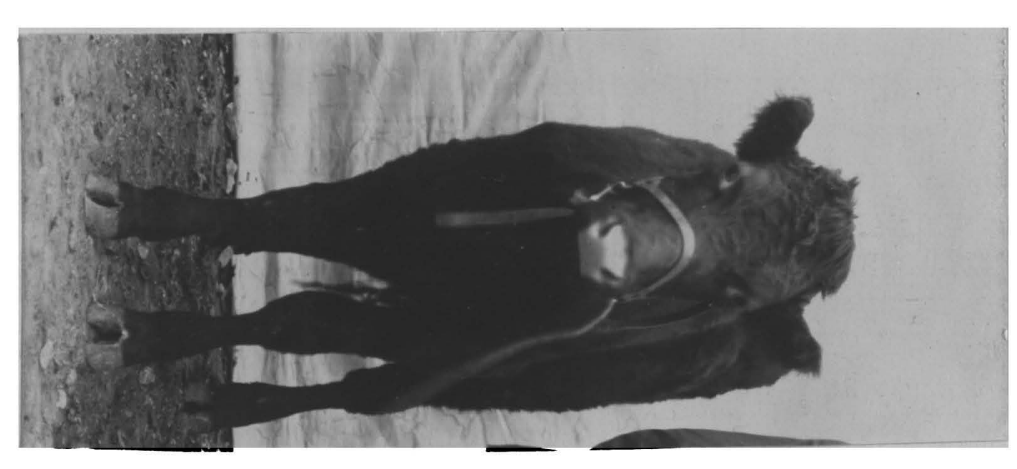

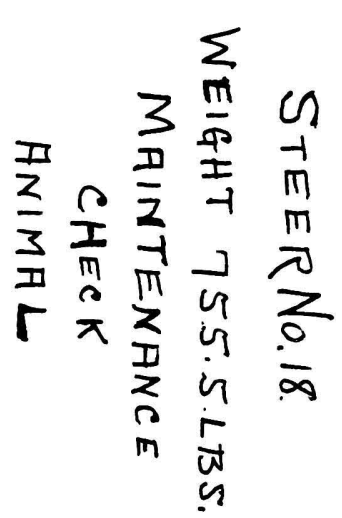
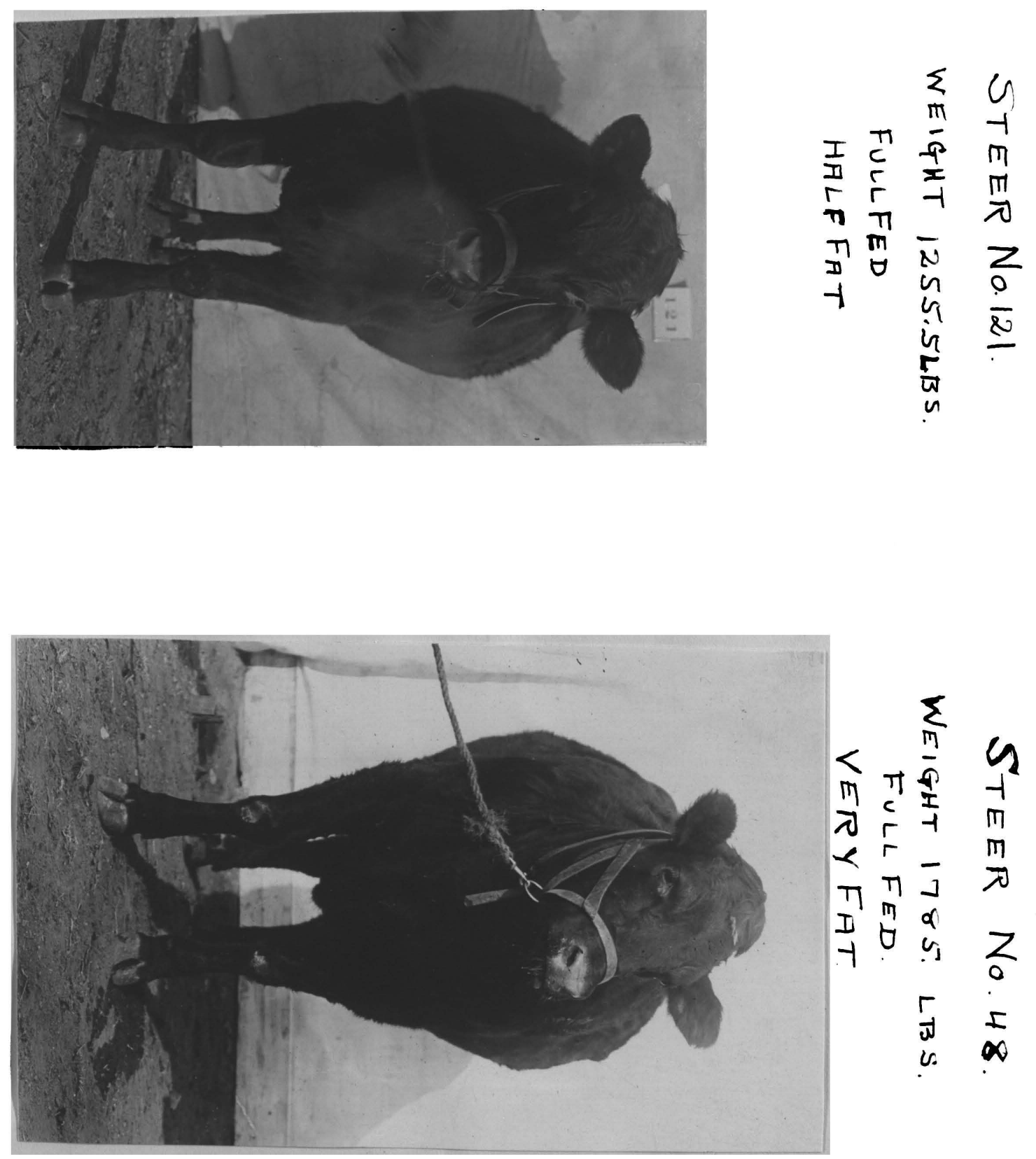

about the same welght they might be considered as one animal fattened to different degrees. It was therefore thought desirable to study the extent a steer might grow during the process of fattening, the age factor thus beling eliminated. Steer No. 18 was chosen as the check animal or starting point to measure the growth of the other two steers, 121 and 48 .

Steer No. 18 lived about two years and eight months. He was slaughtered November 12, 1907 having been on a strictly malntenance ration since July lst, at which time steer No. 48 was put upon full feed. Steer No. 121 was put upon full feed July Ilth, when his condition was judged to be the same as the others on July 1st. At this time the weights of the steers was as follows; No. 18, 755 pounds, No. 121, 770 pounds and No. 48,850 pounds.

Steer No. 18 was kept on a maintenance ration one-hundred and thirty-five days, the final welght taken the morning of the slaughtering was 755.5 pounds. He had had no water since the afternoon before but had had his morning foed. Th1s steer was used to base the measurement of growth of the other two steers, his welght having boen practically constant all this perlod.

Steer No. 121 lived about thlrty-seven months. He was fed one-hundred and flfty-three days on this experiment and on a fattening ration. He was slaughtered December 11, 1907 the inftial weight of this steer was 770 pounds. After one- 

STEER No. 18.

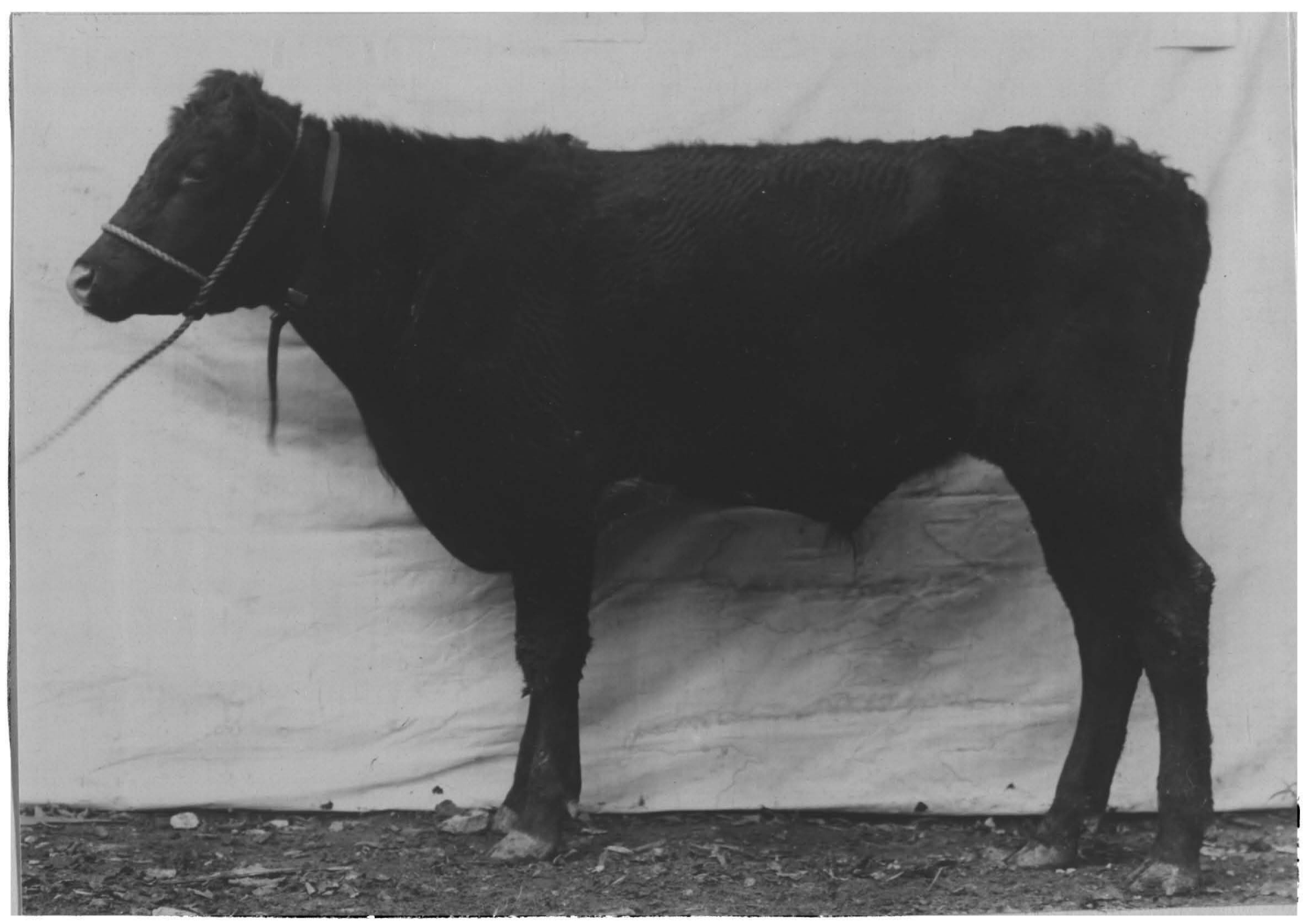

STEER No.121. 

hundred and fifty-three days feeding he galned 485.47 pounds. H1s final weight the morning of slaughtering was 1255.47 pounds. The gain of welght was due to the amount of ration fed, (see Table No. I). Th1s steer is considered to be the same as No. 18 would have been if fed to the same degree. Steer No. 48 can be considered to be about the same as steer No. 18 would have been if fed to the same degree and as No. I2l if fed to the same dogree. He was some heavier at the beginning of the full feeding, but in about the same condition. Th1s steer No. 48 lived about four years and ten months. He was slaughtered January 18, 1909 having been fed flve-hundred and sixty-elght days. During this time he gained 935 pounds. H1s inftial weight was 850 pounds and the final weight the morning of slaughtering was 1785 pounds.

The gain in welght, grain and hay fed and consumed are given in Table No. 1. The grain fed in all cases was corn chop, elght parts and Inseed meal one part, and the hay, alfalfa which was always 0.4 as much as the grain. one-half the grain and all the hay was fed at night. The balance of the grain was fod in the morning. The animals had free access to salt and water during the entire day after the morning feed and welghts were taken, unt 1 the night feed. 



\section{STEER No. 48}

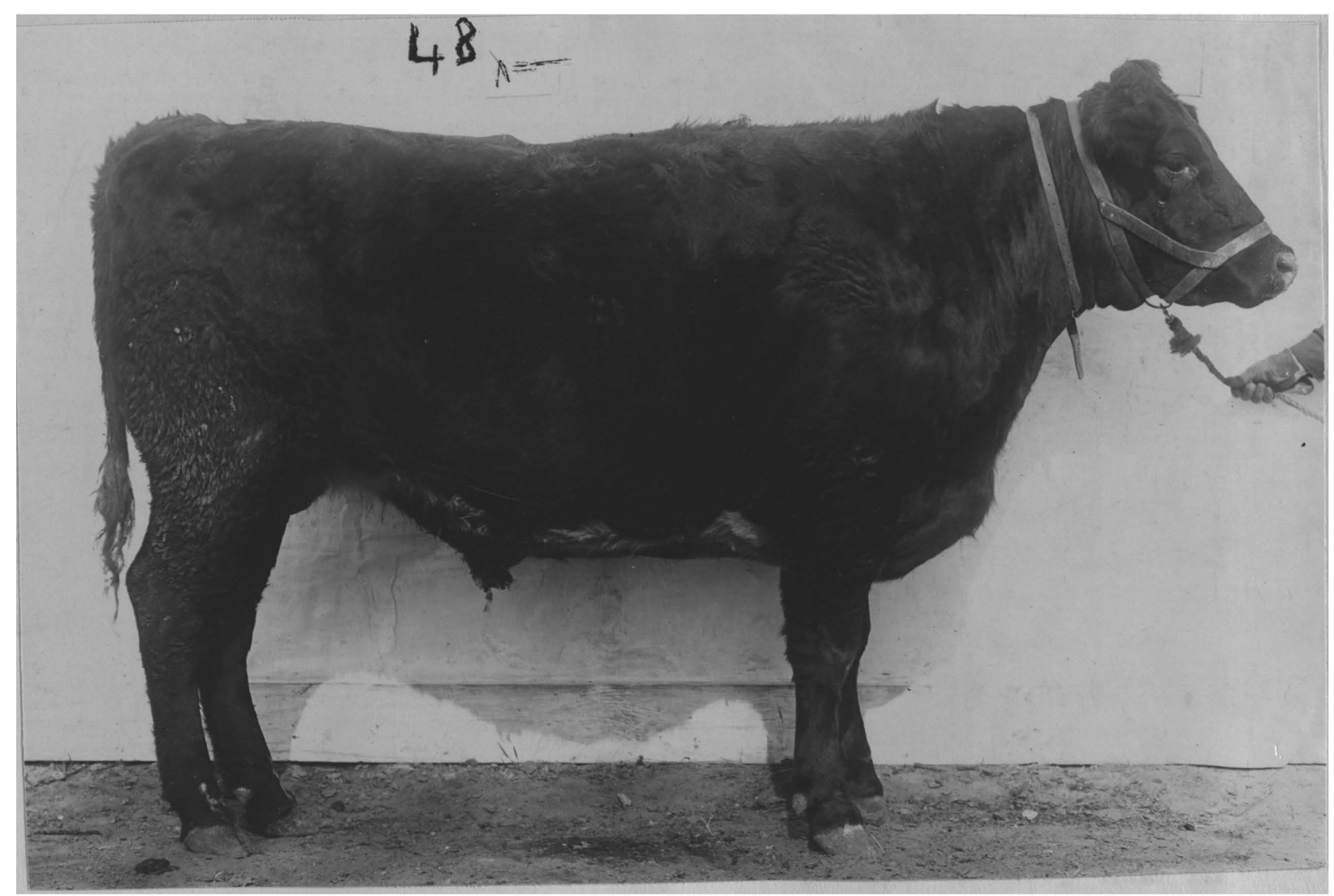

\section{STEER No. 48.}

CROSS SECTION OFRIB BETWEEN 5 th \& 6 th RIBS. LOOKING FT OHE. CHUCK END.

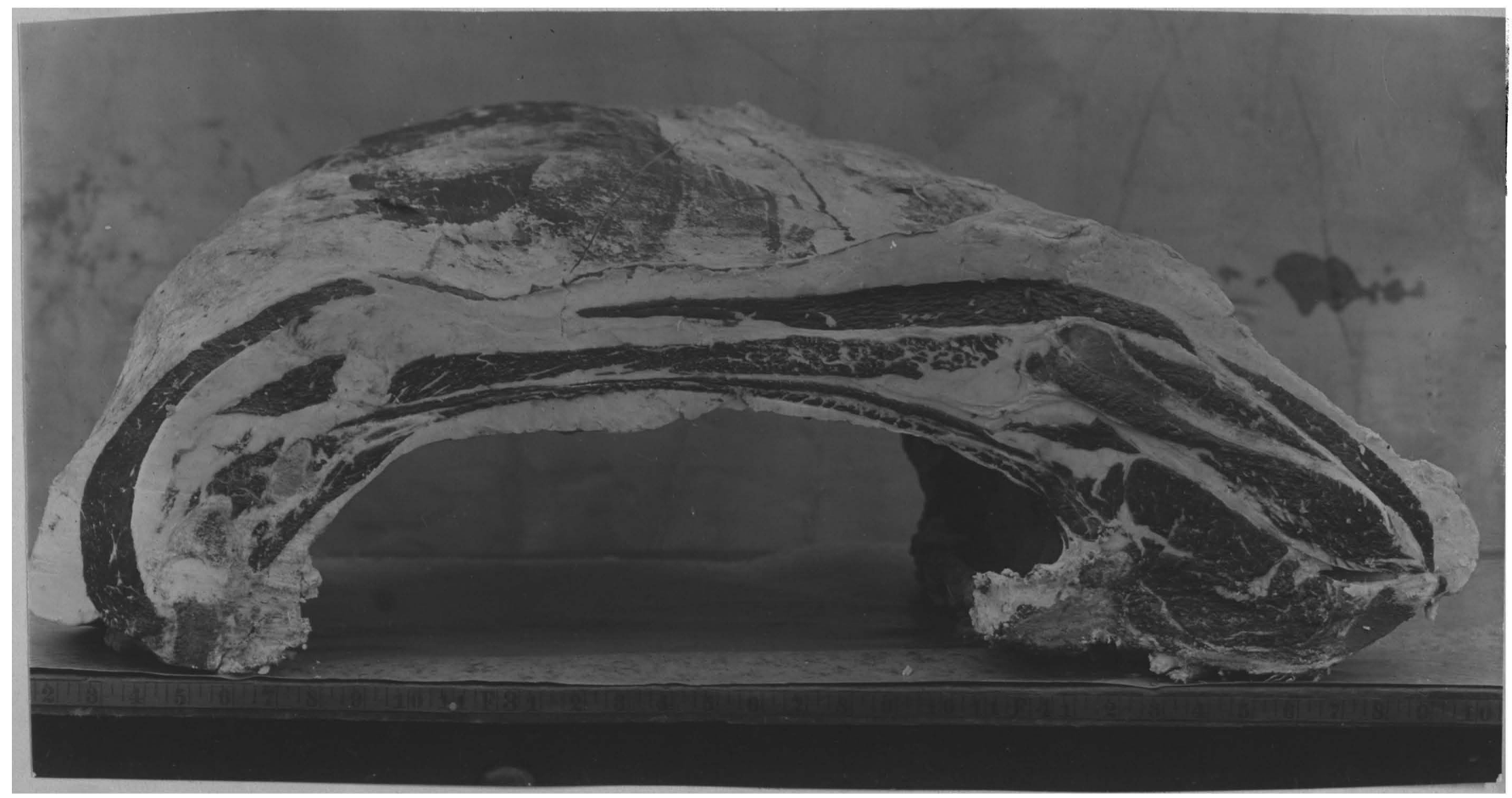



TABLE NO. I.

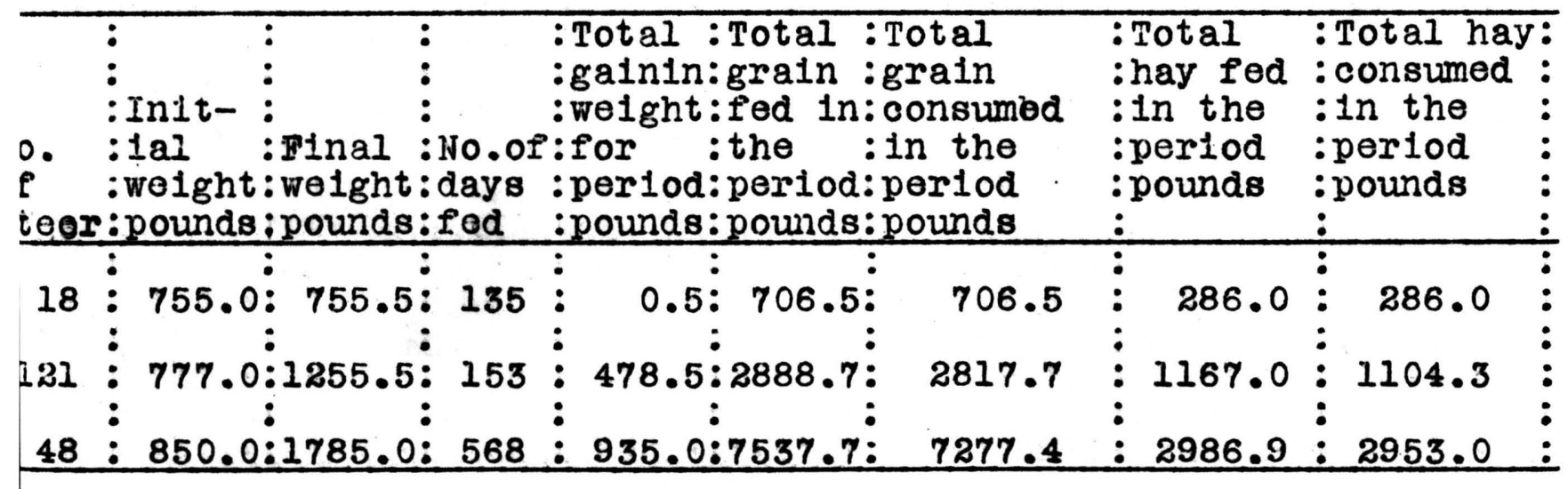

It w1ll be notlced that with steer No. 18, flve pounds of grain and two pounds of hay were required to keep him in maintenance. Therefore all feed above this amount must be used to increase the body parts or to be lald on in the form of fat.

Steer No. 121 consumed 18.42 pounds of grain and 7.22 pounds of hay per day and gained 478.47 pounds in welght for the one-hundred and fifty-three days or 3.12 pounds gain in live weight per day.

Steer No. 48 consumed about 12.81 pounds of grain per day and 5.20 pounds of hay per day. This steer made an average gain of 1.65 pounds per day. The total gain made was 935 pounds. Th1s total gain required a very long time to be put on this animal. It was not an economical gain at all and the steer would have been slaughtered long before if he could have been gotten into the desired condition. He was sick and 

had a bad cough after coming out of the digestion trial all of which showed up badly on his average gain per day.

To understand where this growth takes place and in what form is the object of this investigation.

METHODS EMPLOYED.

The slaughter house was thoroughly cleaned and the animals slaughtered on the coment floor so that any 1088 in handling could easily be recovered. An expert butcher from Kansas Clty did all the slaughtering and dressing of the carcass and another expert from the same place did all the cutting up of the carcass. Th1s insured uniformity in the parts when welghed. All welghts were taken as quickly as possible to prevent 1088 by evaporation.

The animal was kllied, the bleeding done at once and the blood caught in a pan and welghed at once. The offal parts were then removed and after being cleaned wore ground up as soon as possible in the meat grinder. The second day after the slaughtering, the chilled carcass was cut up into the wholesale market cuts. The welghts were taken as soon as possible and then semarated Into lean, fat and bone by hand. The welghts of each of these separated parts was also taken. In several cases the different samples have been composited and ground up together, the sample for analysis being taken from this composite.

The welghts of the different outs are found on Table No.z. 



\begin{tabular}{|c|c|c|c|c|c|c|c|c|c|c|}
\hline Cut or ors & $\begin{array}{l}\text { Stcer llo } \\
: \text { :8 Weight } \\
: \\
: \text { Pounds }\end{array}$ & $\begin{array}{l}\text { :Steer No } \\
\text { :17j. } \\
\text { : Veight } \\
\text { : Pounds }\end{array}$ & $\begin{array}{l}: 48 \text { Weigh } \\
: \text { Pounds } \\
\end{array}$ & $\begin{array}{l}: 0 \\
0 \\
010\end{array}$ & $\begin{array}{l}\text { In of } \\
121 \\
\text { No No. } \\
\text { Pound }\end{array}$ & $\begin{array}{l}\text { :Galn of } \\
: \text { No. } 121 \\
\text { :over No. } \\
: 18 . \text { Percer }\end{array}$ & $\begin{array}{l}\text { :Gain of } \\
\text { :No. } 48 \\
\text { :over No. } \\
\text { tlzlPound }\end{array}$ & $\begin{array}{l}\text { :Gain of } \\
\text { :No. } 48 \\
\text { :Over No } \\
\text { s:l2l. }\end{array}$ & $\begin{array}{l}\text { :Gain of } \\
\text { : No. } 48 \\
\text { : over No. } \\
: 18 . \text { Pounds }\end{array}$ & $\begin{array}{l}\text { : Gain of } \\
\text { : No. } 48 \\
\text { : over No. } \\
\text { s: } 18 . \text { Perce } \\
\end{array}$ \\
\hline & $:$ & $:$ & $:$ & $: 8$ & & $:$ & $:$ & : & • & $:$ \\
\hline Li & 755.50 & : 1255.47 & 85.00 & $:$ & 499.97 & 66 & 53 & 8 & 0 & 27 \\
\hline & 17.75 & .73 & .48 & $\therefore$ & & 1 & & : & & 5 \\
\hline & 85.00 & 129.68 & 168.62 & $\because$ & 44. & 56 & & : & & 8 \\
\hline & 15.50 & 26.29 & 43.24 & $\because$ & & $:$ & : & : & & 17 \\
\hline & 73.00 & 135.50 & $2.1 j .66$ & . & 62.50 & 85 & $:$ & : & 138 & 95 \\
\hline & 1.0 .79 & 10.20 & $56 \cdot 28$ & . & & 77 & 08 & : 19 & & 59 \\
\hline $\mathrm{K} \perp \mathrm{dney}$ and $\mathrm{K} \perp \mathrm{C}$ & 7.01 & 18.45 & 40.56 & $\therefore$ & 11 & : 163.20 & 11 & $: 11$ & & 60 \\
\hline Sum equals Hin & 209.05 & 349.85 & 545.84 & $:$ & 14 & 67 & 19 & : & 33 & 10 \\
\hline 9 & 50 & 76.60 & .40 &. & & & • & $:$ & & 31 \\
\hline $\mathbf{k B}$ & 117 & 174.76 & 262.00 & $\therefore$ & 36 & & & $:$ & 14 & 98 \\
\hline & 7.00 & 7.96 & 10.66 & $\because$ & & & & : & & 29 \\
\hline & 23.00 & 33.99 & 35.16 & $:$ & & & 1 & : & & .87 \\
\hline $\mathbf{e s}$ & 49.00 & 118.02 & 60 & $::$ & 2 & $: 14$ & $:$ & : & $11:$ & $227 \cdot 76$ \\
\hline Sum equajis Forequarters & 237.99 & 411.33 & 597.82 & $\because:$ & 173 & & 18 & : & 359.83 & $151 \cdot 20$ \\
\hline d meat & & 8.90 & 9.56 & $\because:$ & & 18 & 6 & : & 2.06 & 27.47 \\
\hline & & 0 & 38 & 10 & & & & : & 0 & 52 \\
\hline de Marketable & 29 & 4 & 24 & $\because$ & & 2] & 1 & $2^{\prime}$ & & 27 \\
\hline & 3. & 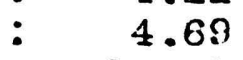 & 67 & $\because$ & & & 0 & : & & 82 \\
\hline & 5.79 & 15 & 00 & $\because$ & & 167.88 & 2 & 1 & 12.21 & 88 \\
\hline toread & $-\infty$ & 2 & 2.58 & $\because:$ & $-\infty$ & --- & 0. & : & - & $\div$ \\
\hline 780 t & : & $:$ & 1.82 & $\because:$ & & & 0 & $: 1]$ & & $\begin{array}{l}17 \\
57\end{array}$ \\
\hline${ }_{0}^{a l}$ fat & $\begin{array}{l}12.57 \\
56.60\end{array}$ & $\begin{array}{l}60.35 \\
65.39\end{array}$ & $\begin{array}{r}136.33 \\
90.75\end{array}$ & $\because$ & $\begin{array}{l}78 \\
79\end{array}$ & $\begin{array}{cc}: & 380 \\
: & 14\end{array}$ & $\begin{array}{l}75.98 \\
25.36\end{array}$ & $\begin{array}{r}: 12 \\
: 3\end{array}$ & $\begin{array}{r}: 123 \\
: \quad 34\end{array}$ & $\begin{array}{l}57 \\
34\end{array}$ \\
\hline equals $\mathrm{m}$ & 39 & 97 & 270.93 & $\because$ & & & $:$ & & & \\
\hline Marketable Carcass & 538.43 & 925.15 & 1414.59 & & 72 & 71.82 & & : & & \\
\hline
\end{tabular}





\section{METHODS EMPLOYED IN CHEMICAL ANALYSES. Determination of Molsture and Fat in Samples of Meat.}

\section{Preparation of the sample.}

The cut or cuts from which the sample was taken were weighed in tared containers, cut in small pleces and ground in the Enterprise meat grinder through three or four different slzed plate holes. Samples were mlxed very thoroughly between each grinding and quartered down if the sample was large. After many mixings to seoure a fairly uniform sample a pint to a quart of the meat was placed in a glass jar and after proper labeling sent to the laboratory or the cooler unt1l needed.

2. Preparation of the Molsture and Fat Tubes.

(a) S \& S extraction shells were filled about onethird full of 1gnited sea sand and absorbent cotton was then stuffed in untll the tube was about three-fourths full. Each tube was numbered. The dry tubes were then placed in an electric oven at $100^{\circ}$ to $150^{\circ} \mathrm{C}$ for flve hours. These were then transferred to a vacuum destccator which was then exhausted and allowed to stand for twenty-four hours with occasional ratation of the deslccator. The vacuum was then reduced by bubbling alr through sulphuric acia. The desiccator was then opened and all the tubes were Immediately transferred to the speclal tared welghing bottle as welghed. 

(b) The glass extraction tubes were then fitted up for the fat samples by covering the bottom of the tube with hardened fliter paper and wirlng it on with a plece of aluminum wire. In the bottom of the tube was placed a small plece of absorbent cotton and sand and absorbent cotton above this as described above for $S$. \& S. extraction tubes.

3. Welghing out the sample.

The sample was very thoroughly mixed agatn and two welghing bottles nearly filled. An aluminum spatula was placed In each welghing bottle and the sample welghed out in triplicate. The extraction shells or glass tubes were assigned, three to each sample. Five grams of the sample was welghed out and placed in an evaporating dish, carefully mixed with the sand from the tube unt1l the mass was homogenous. This was then transferred back to the tube and every particle of sand or sample left in the dish was wiped up clean with parts of the top plug of cotton that was in the tube. This was all put back into the tube again.

4. Determination of the Molsture.

(a) Six Inch vacuum desiccators were used with tight jolnts all around. A medlum heavy grease was used to seal the jolnts. About 200cc of c. p. sulphuric ac1d was placed In the bottom of each desiccator. Only one tube of any one sample was placed in the same desiccator. The alr was then exhausted with a Geryk pump. At intervals of two or three hours the desiccators were rotated to $\mathrm{mix}$ the acid and water 

but not so as to spatter it upon the plate or tubes. In forty-elght to sixty hours the vacuum was released and the tubes transferred to a deslccator which had fresh actd. After rotating every two or three hours for about two days the first dry welght was taken. The welghing was done as described under $2 a$.

The welghed tubes were then placed in a deslocator contalning fresh acld and the above process repeated. The second welghing usually brought a loss of not more than five milligrams. If this was the caso they were called dry and constant, if not the drying and welghing was continued until the 1088 was not more than five milligrams of the preceding wolght.

5. Determination of the Fat.

After the tubes were dried to constant welght in the determination for molsture they were transferred to the soxhlet extraotor and extraoted for sixteon to twenty-four hours with ether distilled over sodium. The ether was placed in the flask. When the extraction was complete the soxhlet was drained and the tube transferred to the electric oven and dried at $50^{\circ} \mathrm{C}$ for an hour. The tubes were then placed in a vacuum deslccator and drled for twenty-four hours. The welght was then taken and the drying continued unt1l the welght was constant. The 10ss in welght represents the amount of fat or ether soluble materlal present. 

The Determination of Nitrogen in the

Fresh sample of Meat.

1. Preparation of the sample.

The sample was prepared the same as for molsture and

fat. See above.

2. Weighing out the sample.

After the molsture and fat sample was welghed out of the welghing bottle, it was used at once for welghing out the samples for nitrogen. Triplicate samples of one gram each were welghed out in the case of lean meat and five grams if fat. Each was wrapped in a \#595 s.\& S. fllter paper and transferred to a properly labeled nitrogen flask.

3. Digestion of the sample.

As soon as posstble after welghing out the sample, 2500 of o.p. sulphur10 aold and 0.7 grams of meroury was added, The flask was put on the frame and digested unt1l all frothing had ceased when about seven grams of nitrogen freo potasslum sulphate was added. The digestion was continued about two hours or unt1l the liquid was colorless. The flasks were then cooled for fifteen to twenty minutes, the neoks of the flasks rinsed down with distilled water after whloh they bolled for one hour more.

4. Distillation and Titration.

(a) Reagents.

1. Standard hydrochloric acld about tenth normal with factor expressed in welght of nitrogen represented 

by one cubic contimeter.

2. Standard ammonium hydroxide about tenth

normal expressed in terms of the hydrochlortc acta.

3. Neutral alcoholfc solution of cochineal for

Indicator.

4. Alkali solution contalning 40 pounds Green

Bank sodium hydroxide, 375 grams of potassium sulphide and thirty liters of nitrogen free distilled water.

(b) Distillation.

About $25 \mathrm{cc}$ of the standard HCL was drawn in

$500 c 0$ wide mouth titrating flasks. About the same amount of distllled water added and one-half a cc of the coohineal 1ndicator. The flask was then connected up with the condenser after recording the amount of acld used. The tube must dip into the acid. The nitrogen flask was fllled about two-thirds full, of distllled water mixed thoroughly and a small plece of granulated zino and a thin plece of paraffin added. Fightyfive co of the sodium hydroxide mixture was then poured carefully down the neck of the flask and the flask then Immediately connected up with the condenser. The flask was shaken and the burnor lighted at once.

\section{(c) Titration.}

When the distillation was complete (volume about $250 \mathrm{cc}$ ) the tube was disconnected and the burner turned out at the same time. The tube was rinsed out with distilied water Into the recolving flask and with the standard amonium hy- 

droxide titration was made to the end reaction of orange to purple.

(d) Calculation of the Results.

Titration to get the factor of the ammonia in terms of the acld was done every day in triplicate. Multiply the co of ammonia used by the factor to convert it into HCL equivalont.

Blank determinations were mun on all the reagents. The amount of HCL neutralized by the blank 18 addod to the HCL equivalent of the ammonia and the sum subtracted from the HCL used by titration. This difierence represents the ce HCL consumed by the nitrogen as ammonia, in the sample. Multiply this number of co by the welght of nitrogen represented by one co to determine the weight of nitrogen in the sample. Multiply this welght by 100 and divide by the welght of the sample to determine the per cent of nitrogen.

Determination of the Ash and Total

Phosphorus in Meat.

1. Preparation of the sample.

Th1s was dono as described under molsture and

fat.

2. Preparation of the Crucibles.

Porcelain cructbles (No. I for fat samples and No. O for lean samples) were numbered and Ignited and welghed In advance. 

3. Welghing of the samples.

The second welghing bottle of the sample prepared for molsture and fat was used for th1s. Ten grams of lean, flfteen grams of fat were welghed out by difference into the crucibles. Triplicate welghings were made on all samples. As soon as posstble the cructbles were placed in the electric oven and thoroughly drled at not exceeding $120^{\circ} \mathrm{C}$ (only $80^{\circ}$ the first two hoursd.

4. Estimation of the Ash. The dried sample was charred in the air with a Bunsen burner at low heat for soveral hours. The heat was gradually increased unt1l the organic matter was completely oxldized. The heat never exceeded a dull red and the ash was not fused. The crucibles and ash were then placed in a desiccator, cooled and welghed. The per cent of ash was calculated to the fresh welght of sample.

5. Estimation of the Total Phosphrous.

After the ash work was completed each cruoible was placed in a $200 c$ Jena Beaker properly marked. Enough nitrlc acld was added ( $\mathrm{pp} . \mathrm{gr} .1 .42$ ) to flll tho cruclble, when $100 \mathrm{co}$ concentrated HCL was added and the beaker then heated on the water bath for two hours adding a little water. The ash was usually dissolved by this time, if not further digestion was required. The cruclble was then rinsed off with distilied water. The contents of the beaker were neutralized with concentrated ammonlum hydroxide. If the 

volume was more than $100 c$ c it was concentrated. A slight excess of concentrated $\mathrm{HNO}_{3}$ and $100 \mathrm{Cc}$ of ammonium molybdate were added and it was then heated to $65^{\circ} \mathrm{C}$ for one hour in an open water bath. It was then allowed to stand about two hours in a warm place. This was then filtered through Swedish filter paper and washod by decantation with a solution of 10 per cent ammonium nitrate. The original beaker containing part of the yellow precipitate was placed under the funnel and the preclpitate on the funnel dissolved with 2.5 per cent strong ammonia and hot water.

The ammonlacal solution of the ammontum phosphomolybdate should not exceed 75cc. Th1s was made nearly neutral with HCL. It was cooled and about $150 \mathrm{c}$ of magnesia mixture were slowly added stirring continually. Twelve ce of concentrated ammontum hydroxide were added when it stood two or more hours. It was then filtered and washed with 2.5 per cent ammonia solution unt1l free from chlorides. The filter paper contalning the residue was put in the crucibles, arled and Ignited to whiteness. Th1s was then cooled and weighed as magnestum pyro-phosphate $\left(\mathrm{Mg}_{2} \mathrm{P}_{2} \mathrm{O}_{7}\right)$. The per cent of phosphorus was then calculated using the $\mathrm{Mg}_{2} \mathrm{P}_{2} \mathrm{O}_{7}$ factor.

Determination of the Total Sollds.

1. Total sol1ds estimated by subtracting the mo1sture from one-hundred. 

Method of Handling the Bone Samples.

1. Securing the samples.

At the slaughter house as the wholesale cuts of meat were made the legn, fat and bone were separated out and the bones were collected for the sample upon which the analyses was to be made. Welghts of the bones were obtained at once and then chopped up with a cleaver to such a size as was best for the bone grinder. The broken pleces of bone were then placed in the bone grinder and ground as completely as possible. The ground bone was then thoroughly mixed and quartered down mlxed again and about a quart taken for analysis and placed in the cooler unt1l ready to use.

2. Welghing out the samples.

The sample from the quart jar was then mixed again and Immediately three small, tared evaporating dishes were fllled and rapldiy welghed. The sample should be between thirty and fifty grams.

3. Determination of the Molsture in the Bone. The evaporating dishes containing the welghed samples were placed in vacuum deslccators and the molsture determined as under molsture in meat. The dishes could not be placed in closed containers while welghing so they were welghed as rapidly as possible to a milligram.

4. Fat Determination in the Bones. The soxhlet extractors were fitted up with a small plece of absorbent cotton in the bottom and a plece of tightly fltting filter paper on top of this. The bone was 

then transferred to the extractor taking care not to lose any. The dish and spatula used in this operation woro cleaned with ether and this poured into the extractor also. A tared and numbered Erlenmeyer flask with a tightly fitting ground glass top was fllled about ono-third full of good dry fat free ether. The flask was then connected with the extractor and the bone extracted for about twenty to twenty-four hours. The ether was then allowed to slphon off and the bone taken out and placed in a properly labeled jar. The extractor was again conneoted up and the ether distilled off from the flask and removed from the extractor before it could siphon back. In this way the ether was removed and the fat extracted was left below.

Th1s fat and flask was then drled in vacuuo as previously described. The fat was thus welghed directly. The por cent of fat was then calculated from the original welght of sample.

5. Analysis of the Extracted Bone. The triplicate samples were combined after extraction. They wore finely ground so that it would pass through a $1 \mathrm{~m} . \mathrm{In}$. sleve. Molsture, nitrogen, ash and phosphorus wore then determined in the usual way on this ary fat free bone. The per cents were caloulated to a molsturo froe basis. 

DISCUSSION OF RESULTS.

As would be expected, it is found that all the cuts of meat in the carcass, loln, round, chuck, plate, flank and so on, have galned in welght in the case of the steers Nos. 121 and 48. Steer No. 121 being considerably heavier than steer No. 18 and steor No. 48 than steer No. 12l. The hindquarters of the carcass of No. 121 were 140.8 pounds heavier than those of No. 18. This is a gain of 67.35 per cent. Similarly the hindquarters of No. 48 welghed 196 pounds more than those of No. 121. Th1s ts a gain over No. 121 of 56.02 per cent, or a gain of No. 48 over No. 18 of 336.8 pounds, equal to 161.1 per cent. The forequarters of the carcass of No. 18 welghed 237.99 pounds wh1le those of No. 121 welghed 411.33 pounds. A gain of 173.34 pounds or 72.83 per cent while the same parts In steer No. 48 welghed 597.82 pounds, a gain of 186.49 pounds or 45.34 per cent over No. 121. The forequarters of No. 48 we1ghed 359.83 pounds more than those of No. 18, a gain of 151.2 per cent.

A heavier hindquarter is desired because of the larger amount of high priced meat in that region such as the loin and round. Therefore the heavier the hind quarter the more economical the animal 18 to the butcher.

It is possible that the hindquarter increases more in welght than the forequarter the longer an animal is fed but more data would be required to substantiate this. 

- The miscellaneous parts such as the brain, tongue, liver, and so on are given in Table No. 2 also, although they are not part of the carcass proper they are salable. All these parts also show a gain in weight. No. 121 over No. 18 and No. 48 over No. 121 .

The total weight of marketable parts for steer No. 18 was 538.43 pounds against 925.15 pounds for steer No. 121 and 1414.59 pounds for steer No. 48. Th1s means a gain for No. 121 over No. 18 of 386.72 pounds or 71.82 per cent in onehundred flfty-throe days moro feeding. Also that steer No. 48 galned 489.44 pounds or 52.9 per cent over steer No. 121 in four-hundred and fifteon days more feeding. He gainod over steer No. 18 in flve-hundred and sixty-eight days more feeding, 876.16 pounds or 162.72 per cent. Th1s 18 gain in salable portion of the carcass only.

Referring to Table No. 3 it 18 notioed that the offal parts, including blood, hide, clrculatory system, resplratory system, nervous system, and digestive system total, had increased in total weight from 153.20 pounds for steer No. 18 to 228.13 pounds with steer No. 121 and to 276.16 pounds for steer No. 48. A total gain in these parts for steer No. 121 over steor No. 18 of 74.93 pounds or 48.91 per cent and of No. 48 over No. 121 of 48.03 pounds or 21.05 per cent. These weights however include the hide. Th1s 18 salable and has grown from 56.60 pounds in No. 18 to 65.39 pounds with No. 121 wh1le 

No. 48 has grown to 90.75 pounds:

The total skeleton excluding the horns, hoofs and teeth, weighed 128.76 pounds with steer No. 18 and 145.58 pounds w1th steer No. 121. A gain of 16.82 pounds or 13.06 per cent. The skeleton of steer No. 48 woighed 174.67 pounds a gain over No. 121 of 29.19 pounds or 20.05 per cent.

The welght of blood would be expected to increase also with the increase in size and live weight. Th1s is found to be the case. The weight of blood with steer No. I2I was 53.86 pounds while the blood of No. I8 woighed 34.39 pounds. A gain of 19.47 pounds for No. I2l. Thls gain was equal to 56.61 por cont. The blood of No. 48 weighed 56.51 pounds a gain of only 2.65 pounds or 4.92 per cent over No. 121. These welghts of blood were taken by weighing the blood immedlately after the bleoding ceased. It was caught in a pan held under the inotision in the jugular voin in the neok.

The clrculatory system consisting of the heart, heart fat, perloardium, large arterles and velns in the cavity of the thorax, had increased in welght in the proportion expected. In steer No. 18 tt welghed 5.72 pounds. In steer No. 12I It had gained 3.70 pounds or 64.69 per cent weighing 9.42 pounds. In steer No. 48 it had gained 5.53 pounds or 58.70 per cent over No. 121 weighing 14.35 pounds.

These Increases in welght are probably due to the amount of fat stored up around the heart rather than to such a large increase in the welght of the organs themselves. 

TABLE NO. 3 .

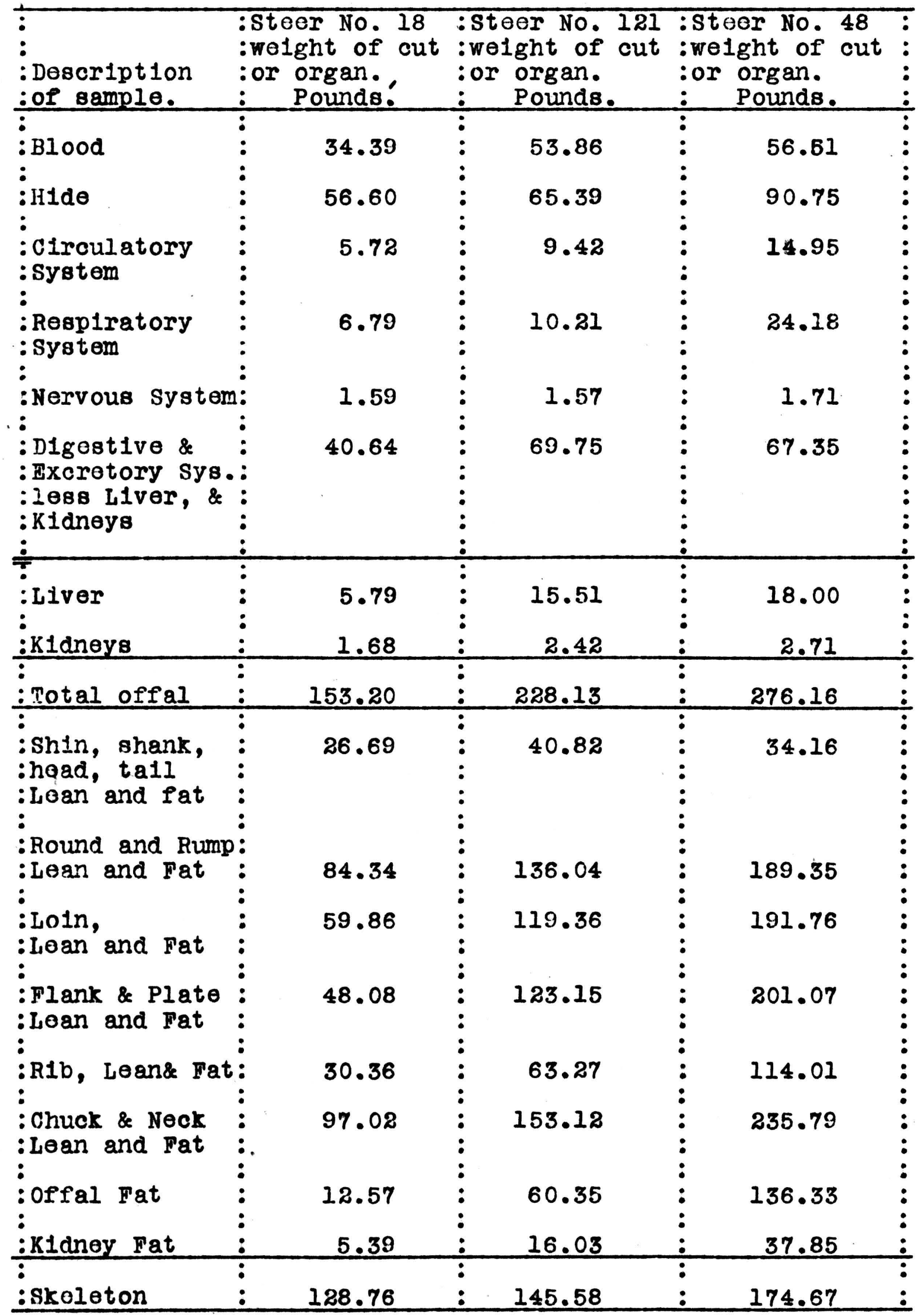



- The nervous system is not found to grow much showing that the storage of fat in the body probably does not effect the size of the brain and epinal cord.

The digest1ve and exoretory system has grown a great deal with No. I2I. The welght of this system in No. 18 was 48.11 pounds and that of No. I2l was 87.68 pounds a gain of 39.57 pounds or 82.25 per cent but that of No. 48 did not grow proportionately. It was slightly more than that of No. I2l beling 88.05 pounds or a gain of only 0.37 pounds. It would be natural to suppose that No. 48 would show a marked increase in size or weight of the digestive and excretory system but perhaps this 1s the maximum limlt of growth in these organs, about 88 pounds.

The differenoe in the total welght of the digestive and excretory system of the two steers No. I2l and No. 4818 very small indeed. But now if we should add to this total weight of the system, the hand separated offal fat, the weight of the digestive and excretory system for No. I2l would be 148.04 pounds and for No. 48 it would be 224.38 pounds. Th1s means, If we would consider the fat and all, No. 48 would show an Increase over No. I2I of 76.34 pounds which is equal to 51.57 per cent a very striking gain, but almost this entire gain 1s fat. But now if we should deduct the entire fat, which was determined by analysis in the oase of No. 121 amounts to 68.46 pounds and for No. $48,138.84$ pounds. If we do this 

then, we would get as a result the true welght of the digestive and excretory system without 1t's fat. If we do this we find that the weight of this system in No. 12l, then 1879.58 pounds and in No. 48, it is 85.54 pounds. The difference between these welghts then shows the actual gain in this system less 1t's fat. Th\$s gain is 5.96 poundis or 7.49 per cent. Thus Instead of No. 48 showing practically no gain at alI (0.37 pound) in his digestive and excretory system, excluding the fat which the system contained, No. 48 gained 5.96 pounds or 7.49 per cent over No. 12l. The gain in actual analytical fat amounted to 102.80 per cent.

The gain was mostly fat then, and amounted to 51.57 per cent (if we consider the hand separated fat in the weight). Leaving out the fat, the gain amounted to 7.49 per cont which probably measures the aotual increase in the substance making up this systom exclusive of fat. The alfference in the percentage gain of the analytical and hand separated fat was probably in part due to incomplete separation.

For the sake of comparison with this digestive and excretory system wo may take the lo1n. The following figures show the weights of the loin, loan and fat and analytical fat in each of No. 48 , and No. 121 . 



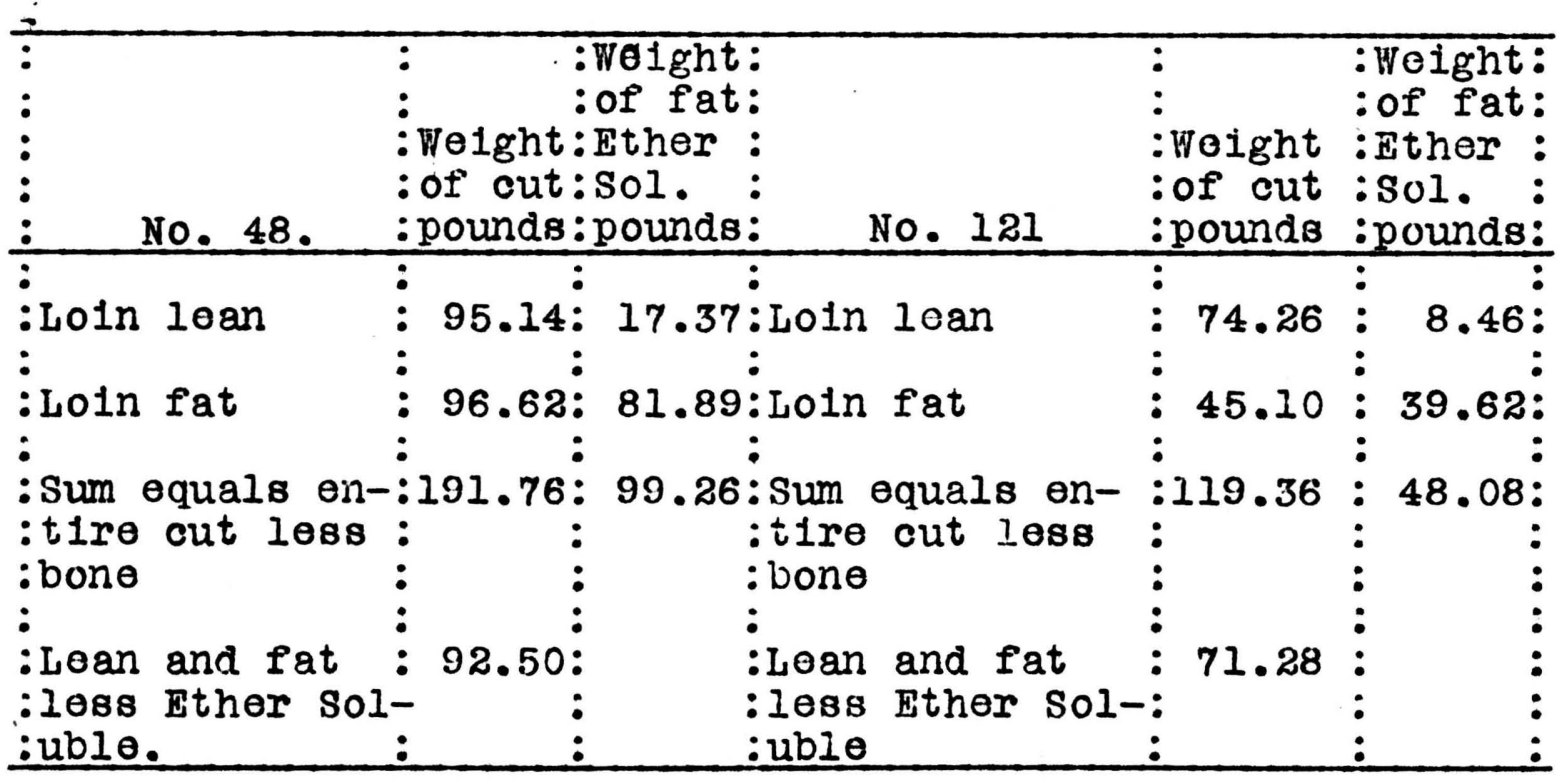

This shows that the lean and fat (hand separated) in No. 48 welghed 191.76 pounds of whlch 99.26 pounds was pure fat or other soluble materlal. The difference between these two flgures then show that the loin cut, less the bone and ether soluble fat, welghed 92.50 pounds. The same kind of results are flgured for No. 12l, which shows that he had 71.28 pounds of non fat material in the loin cut (excluding bone). Th1s means a gain of No. 48 over No. 121 of 60.7 per cent in the lean and fat cut but the gain in non fat materlal was 29.7 per cent, about one-half. That is to say that when the gain in the lean and fat is considered, it is about twice the gain in the lean substance and t1ssues. The actual gatn of the pure ether soluble fat, No. 48 over No. 121 amounted to 106.4 per cont. 

Th1s shows that at the condition of No. 48 , the lean meat substance or non fat matorial grows not more than half as much as the fatty materlal considering the ontire cut (less the bone). The pure ether soluble fat had increased over one-hundred per cent.

The above data shows that even though the digestive and excretory organs increased 7.49 per cent in actual non fat materlal in the case of No. 48 over No. 121, st1ll the non fat (mostly lean meat) material in the loin cut had increased 29.7 per cent.

The total length of intestines in steer No. 121 was 188 feet, whlle the length in steer No. 48 was 184 feet.

Taking up the comparison of the wolghts of the IIvers of the three steers, the IIver of No. 18 welghed 5.79 pounds while that of No. I2I was 15.51 pounds. A gain of 9.27 pounds. The IIver of steer No. 48 weighed 18.00 pounds a gain over No. 121 of 2.49 pounds. This sœms a rather small gain for this organ in such a large antmal.

The kldneys show practically the same thing. Those of No. 18 welghed 1.68 pounds against 2.42 pounds with No. 121 and 2.71 pounds with No. 48. The gain 1s marked between No. 18 and No. 121 but between No. 121 and No. 48 it 1s hardly appreclable. Individual variation could have easily accounted for 1t.

The shin, shank, head and tail lean and fat were all com- 

bined into one sample. They represent the cheapest parts of the animal.

It will be noticed in the first column of Table No. 3 the shin and shank head and tall sample welghod 26.69 pounds In the case of No. 18 and with steer No. 121 the weight was 40.82 pounds (Table 3 second column) a gain in weight of 14.13 pounds wh1le the same sample in No. 48 welghed 34.16 pounds (see Table 3 third column). This a loss for stevr No. 48 compared to No. 121 of 6.66 pounds. Th1s loss cannot be accounted for except that No. 48 was a more leggy animal. The round and rump lean and fat sample in the case of stoer No. 18 welghed 84.34 pounds and with steer No. 121 it welghed 136.04 pounds a gain in weight of 51.70 pounds while with steer No. 48 it welghed 189.35 pounds a gain over No. 121 of 53.31 pounds.

The loin loan and fat sample shows an inorease also. With No. 18 it welghod 59.86 pounds and with No. 121 it was 113.36 pounds a gain of 59.50 pounds. W1th No. 48 it weighed 191.76 pounds a gain in welght over No. 121 of 72.40 pounds. Th1s Is Indeed a gratifying result for the loin is ouch an expensive cut.

It is found that the flank and plate lean and fat sample had also increased in welght but a greater amount although this is a cheap plece of meat. In No. 18 it weighed 48.08 . pounds and with No. 121 it wolghod 123.15 pounds a gain of 

75.07 pounds wh1le with No. 48 it welghed 201.07 pounds a gain over No. 121 of 77.82 pounds.

The chuck and neck also gained the same though not so much with No. 121. It welghed 97.02 pounds with No. 18 and 153.12 pounds with No. 121 a gain of 56.10 pounds and with No. 48 it weighed 235.79 pounds a gain of 82.67 pounds over No. 121.

The offal fat including the fat around the intestines, stomach and caul weighed 12.57 pounds with No. 18 and with No. $121,60.35$ pounds a gain of 47.78 pounds or 380.11 per cent. It weighed with No. $48,136.33$ pounds a gain over No. 121 of 75.98 pounds, which is equal to 125.73 per cent. No. 48 gained over No. $18,123.76$ pounds which 1s equal to 984.57 per cent.

The kldney fat, one of the great storage places for fat In the body, welghed in No. I8 only 5.39 pounds as trimmed out in the wholesale market. In No. I2I it weighed 16.03 pounds a gain of 10.64 pounds or 198.14 per cent, and with No. 48 It woighed 37.85 pounds a gain over No. I2I of 21.82 pounds or 136.03 per cent. No. 48 galned over No. 18, 32.46 pounds which 1s equal to 602.23 por cent.

Referring again to Table No. 2 , the fifth column shows the actual percentage gains in the carcass cuts of steer No. 121 over No. 18 and the seventh column of No. 48 over No. 121 . This shows that with the exception of the shanks, flanks, chucks, necks, brain, tongue and hide, the percentage Increase 

-In the welghts of the cuts is decreased in steor No. 48 over No. 121. Generally spoaking then, the percentage gain in the welght of the wholesale market cuts and salable portion of the carcass tends to decrease after a certain period in the fattening process 18 roached. The ninth column shows the actual percentage gain of No. 48 over No. 18. The seventh and ninth columns then, show the increase due to feed consumed. In Table No. 4 is given first, the percent of the wholesale market cut or organ to the live weight of the animal, steor No. 18. The second and fourth columns are theoretical percentages. The second shows by means of the inorease in wolght of No. 121 over No. 18, what percentage of the body weight this weight of cut would have been if steer No. 18 had attalned the proportions of steer No. 121. The third column shows the amount of 1ncrease this would be in per cent. since we aro considerling all three of these steers as one and the same but fattened to different degrees, we can show how much increase we might expect in the different length of feeding . perlod and amount of grain fed. The fourth column shows the same thing for No. 48 calculated to No. 18 as a basis of gain. The fleth column shows what this incroase would amount to if No. 18 had been fed flve-hundred and sixty-elght days,

It will be notloed that with No. 48 with five-hundred and sixty-elght days more foeding than No. 18, the hindquarter would gain nearly 45 per cent and the forequarter nearly 48 per oent and the miscollaneous parts about 24 per cent. Th1s 

would make a total gain that we might expect for the marketable carcass about 116 per cent with the five-hundred and sixtyelght days fosding. However it is observed that with steer No. 121 whlch had only one-hundred and fifty-three days foedIng the gains we might expect are nearly one-half those of No. 48 on five-hundred and sixty-elgint days feeding.

It was found that No. 18 dressed out 59.68 per cont. That 18, the carcass was that per cent of the live weight. Steer No. 121 dressed out 60.50 per cent and steer No. 48 dressed out 63.97 per cent. Th1s $1 \mathrm{~s}$ about 3.5 per cent better than No. 121 and about 5 per cent better than No. 18.

It has been shown that the hind and forequarters and the miscellaneous parts of the body have grown in size and volume w1th steers Nos. 121 and 48 . Steer No. 48 however not as a general rule Increasing so much over No. 121 as the latter did over No. 18. The carcass 1tself is the important part of the animal and the increase in this part has been shown for welghts of cuts and percentage increases on Table No. 2. Now to learn what part of the animal has increased, the weights of the hand separated lean, fat and bone in each cut were taken and calculated to percentage of Increase as shown in Table No. 5 .

It 18 found in No. 18 that the lean meat (hand separated) amounted to 297.87 pounds or 39.43 per cent of the body weight. With steer No. 121 the lean meat wolghed 446.42 pounds or 35.56 per cent and with No. $48,536.83$ pounds or 30.07 per cent of the body welght. On the basls of 1000 pounds IIve 

THEORETICAL PERCENTAGE OF GAINS.

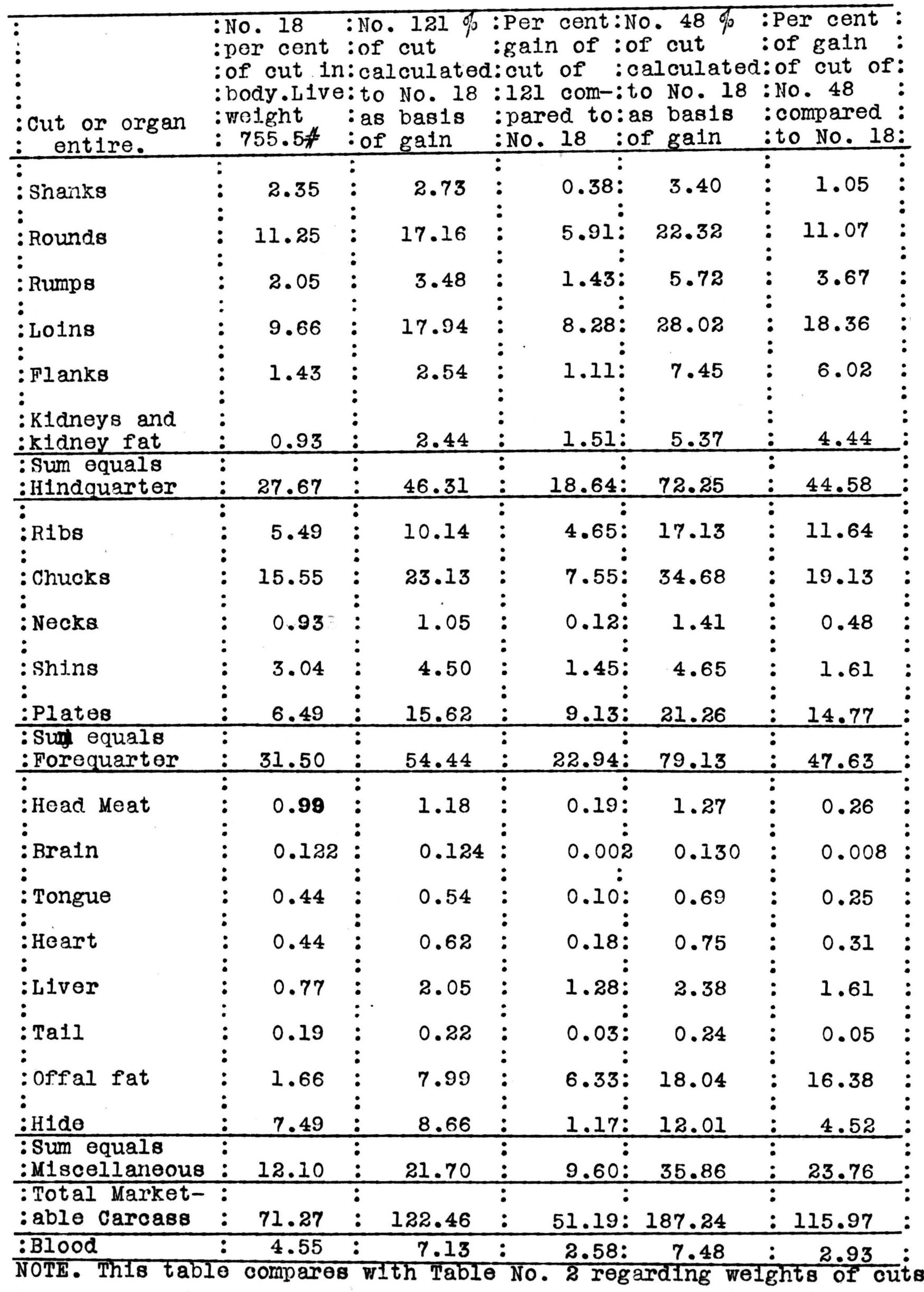



welght for each steer No. 121 will contain 9.81 per cent less lean meat than No. 18. Simllarly No. 48 would have on basis of 1000 pounds I1ve weight 15.44 per cont less lean than No. 121 and 23.44 per cent less lean than No. 18 .

This shows as did Table No. 2 that the longer the animal was fed the porcentage of the lean meat in the cut decreased.

Table No. 6 shows the welght of the hand separated fat In the different cuts of the right half of the steers and the percentage increase of this fat during the process of fattening. This table shows that the fat in the body excluding the offal fat for steer No. 18 welghed 55.46 pounds or 7.34 per cent of the live welght. With steer No. I2l the fat wolghed 207.89 pounds or 16.56 per cent of the live welght and steor No. 48 the total fat excluding the offal fat weighed 468.69 pounds or 26.26 per cent of the Ilve weight. Th1s means an increase of fat of No. 121 over No. 18 of 274.85 per cent and an increase with No. 48 over No. 121 of 125.46 per cent and over No. 18 of 745.10 per cent. Calculated on basis of 1000 pounds live welght No. 121 had galned 125.61 por cent over No. 18. No. 48 had gainod 58.57 per cent over No. 121 and 256.40 per cent over No. 18. Fvery cut has galned from 131 per cent to 423 per cent in welght of fat with steer No. 121 over No. 18. With stoer No. 48 there is a gain over No. 12l, with two or three exceptions, of less than No. I2I gained over No. 18. There sooms to be a general decline in 
TABLE HO. 5 .

WEIGHT OF HAND SEPARATED LEAN MEAT

IN THE DIFFERENT CUTS.

(Right half only)

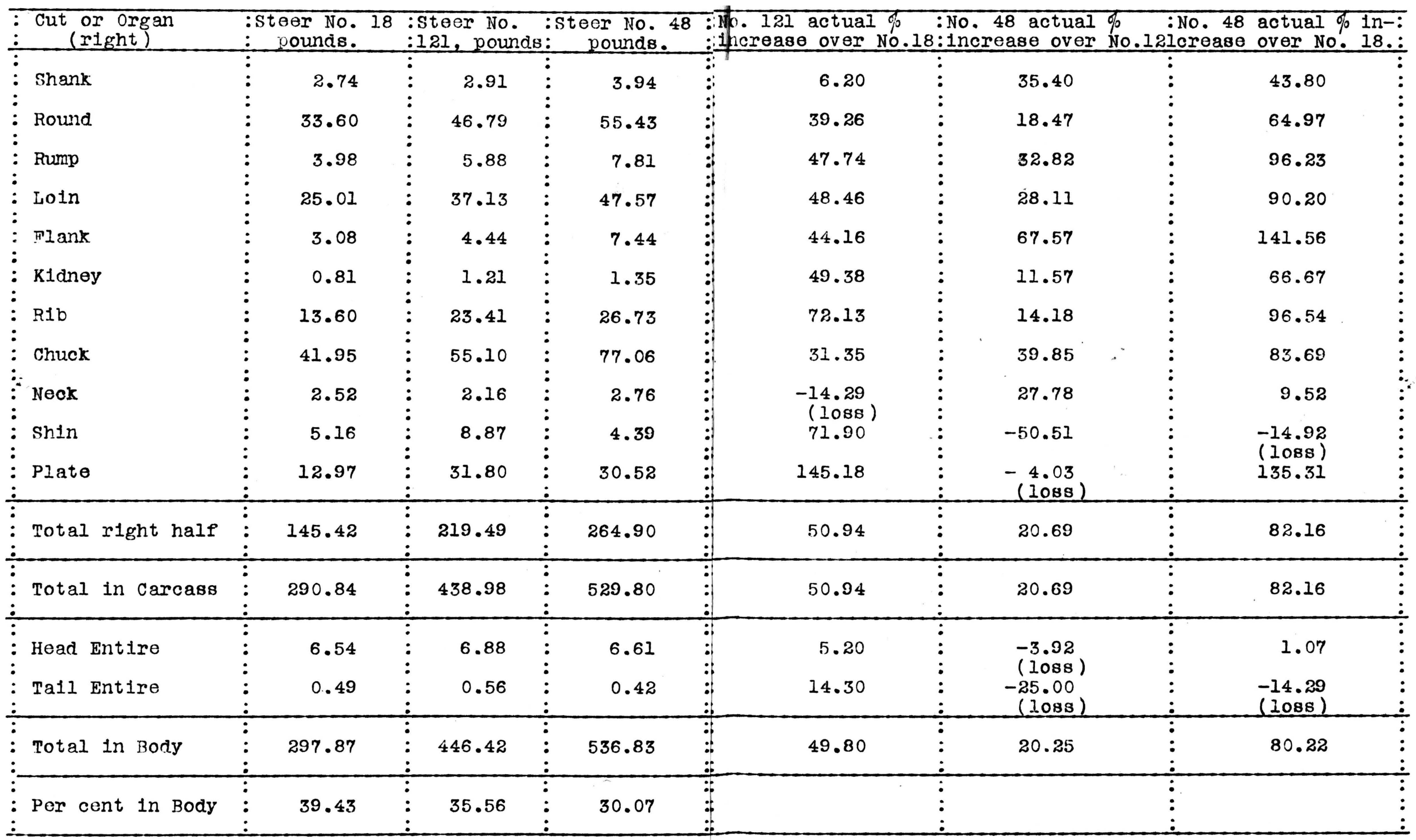


TABLE NO. 6 .

WFIGHT OF HAND SEPARATED FAT IN

THE IITF ERENT CUTS

(RIght half only)

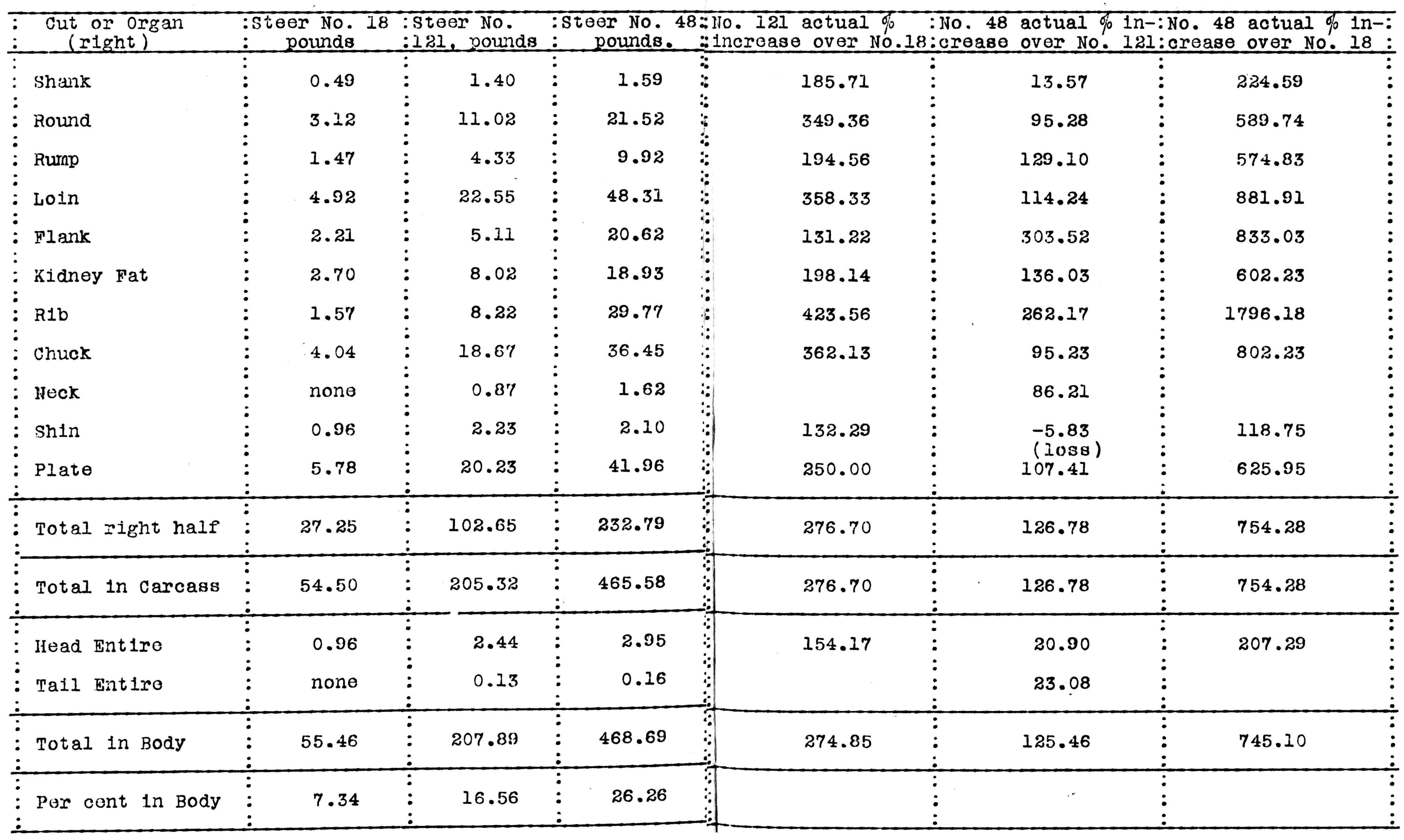


TABLE NO. 74

WEIGHT OF HAND SEPARATED BONE IN

THE DIFTERTN CUTS.

(Right half only)

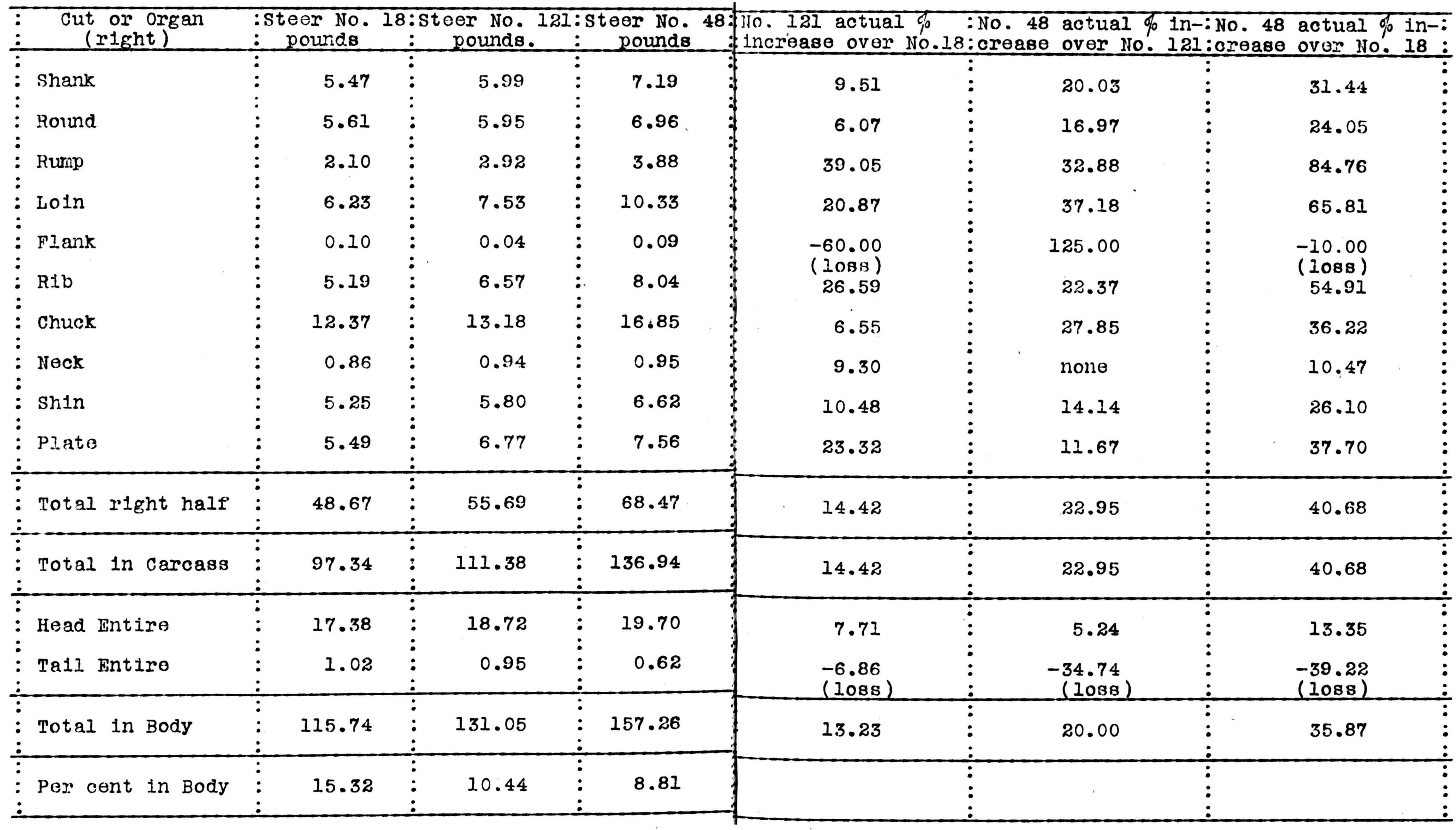



in porcentage of gain after a certain linit $1 \mathrm{~s}$ reached in the fattenlng process. The last column shows the gatn of No. 48 over No. 18. This is a very large amount, notice espectally the rib with 1796.18 por cent. It would soem that the robs hold in reserve the most fat.

Table No. 7 shows the welghts and percentages of gains In the hand separated bone in the cuts. It was found that the bone in the body excluding the feet weighed with No. 18, 115.74 pounds or 15.32 per cent of the body weight. With steer No. 121 the corresponding weight of bone was 131.05 pounds or 10.44 per cent of the body weight. With steer No. 48 the simflar weight of bone was 157.26 pounds or 8.81 per cent of the body welght.

These welghts of bone in the body show that No. 121 had Increased over No. 18, 13.23 per cent and No. 48 over No. I2I, 20 por cent having grown in size that amount which may be attributed to the excess of food supply and the longer feeding. But oven deducting tho fat in the skeletons which in No. 121 amounted to 30.94 pounds and in No. $48,37.66$ pounds, the percentage Increase of No. 48 over No. 121 was 19.43 per cent.

The ash constituents of the skeleton of No. 48 have increased, from 37.90 pounds with No. 121 , to 47.57 pounds w1th No. 48 , an amount equal to 25.51 per cent. The protein content of the skeleton of No. 48, had increased 100.10 per cent over that of No. 121. The weight of 

STEER No.18.

Inside View of Chrcass (right Half)

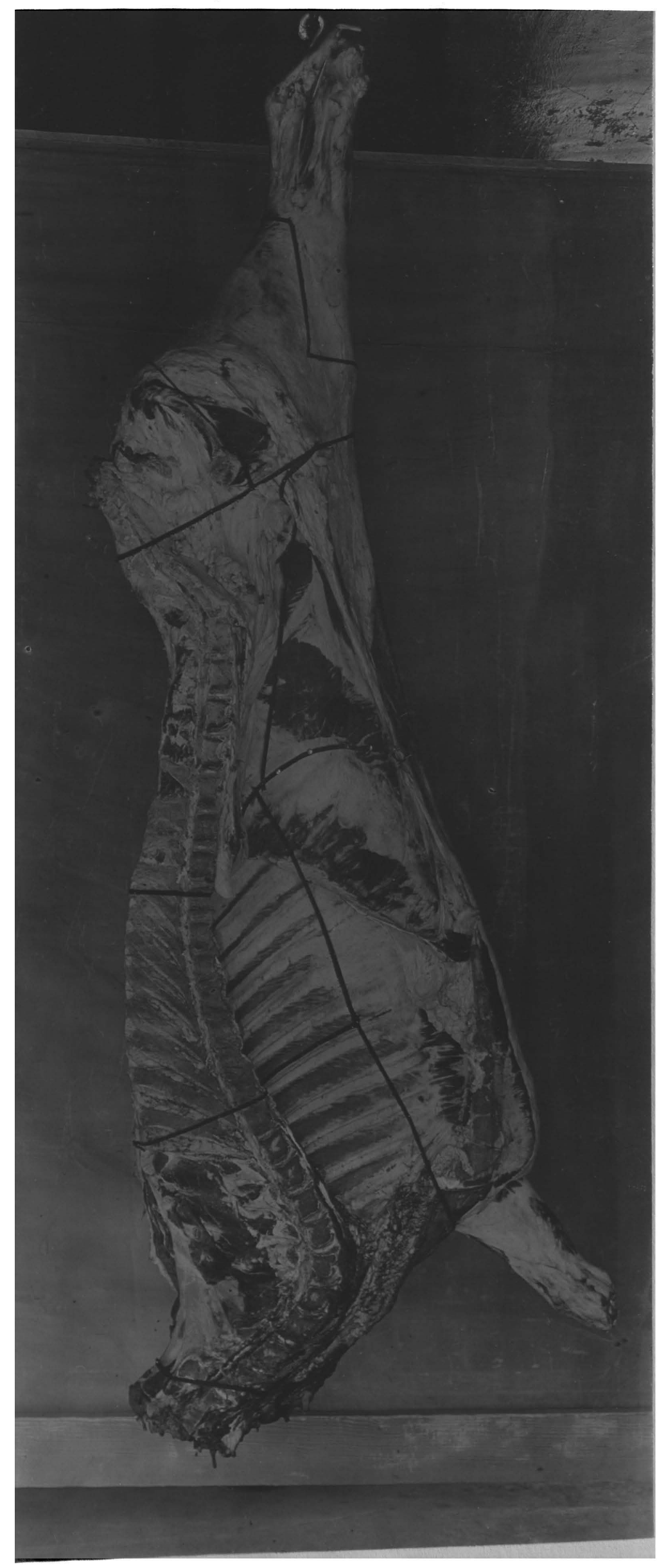



STEET No.121.

INSIDEVIEW OFCARCASS (RIGHTHALF)

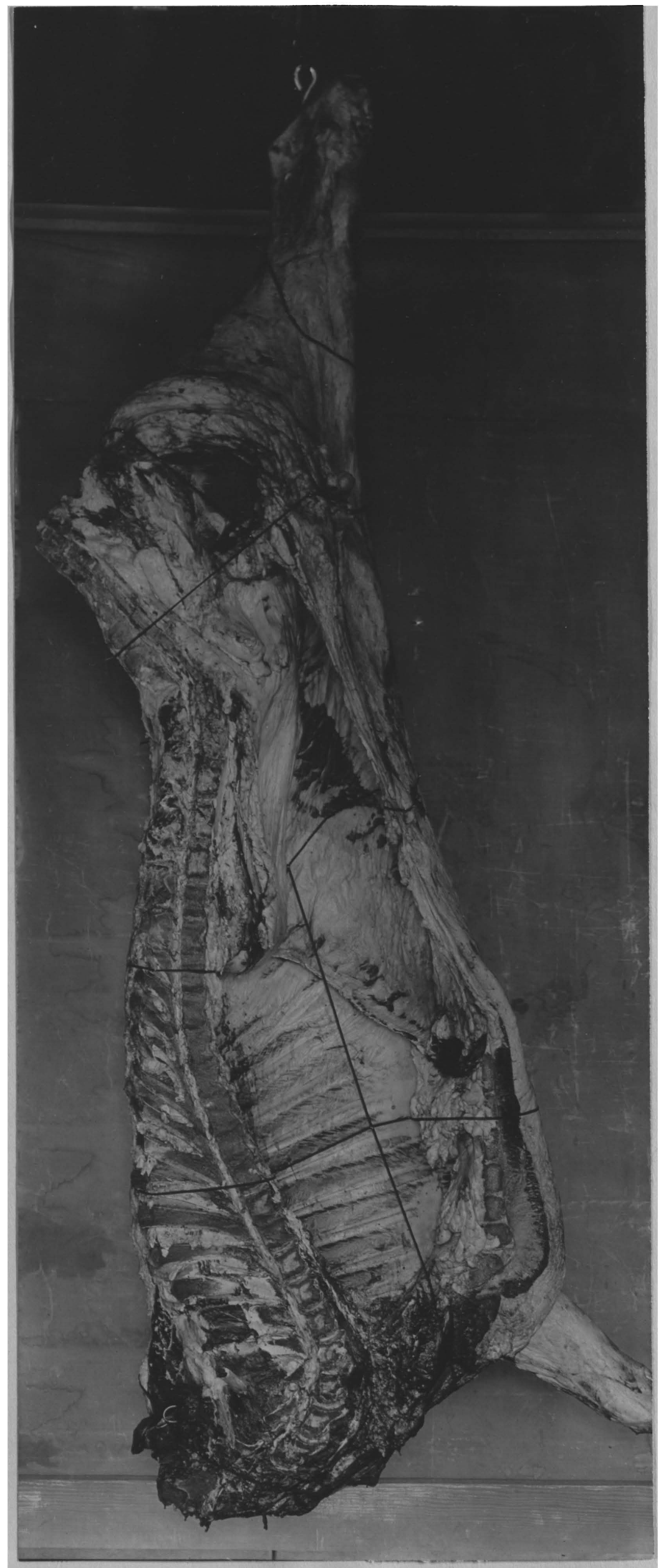



STEER No.48.

INSIDEVIEW OFCAREASS (RIGHT HALF)

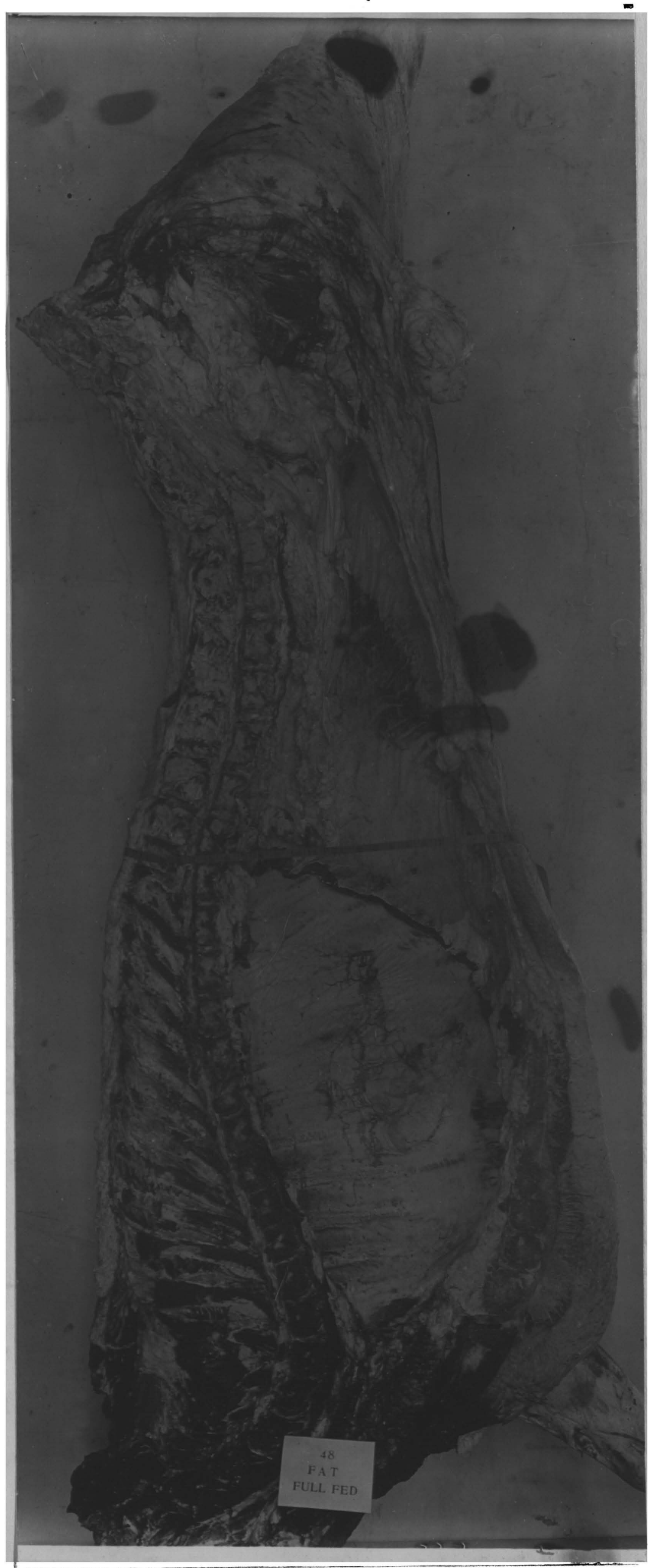



protein in No. 48 being 59.61 pounds and in No. $121,29.79$ pounds.

TABLE NO. 8 .

SUMMARY OF LEAN, FAT AND BONE.

(hand separated.)

\begin{tabular}{|c|c|c|c|c|c|c|c|}
\hline : & & & & & $\begin{array}{l}\text { :steer No. } \\
: \quad 18 .\end{array}$ & $\begin{array}{l}\text { steer No. } \\
: \quad 121 \\
\end{array}$ & $\begin{array}{l}\text { Steer No. } \\
: \quad 48 \\
\end{array}$ \\
\hline :Per & cent & of & Lean & In Body & 39.43 & 35.56 & 30.07 \\
\hline$\vdots " 1$ & $"$ & $"$ & Fat & $"$ & 7.34 & 16.56 & 26.26 \\
\hline$\vdots n$ & $n$ & $n$ & Bone & $n$ & 15.32 & 10.44 & 8.81 \\
\hline
\end{tabular}

Table No. 8 1s a summary showing the per cent of loan, fat and bone in the bodies of the three steers.

The following figures show the weight of bone, lean and fat in throe steers and the gain in weight of these parts.

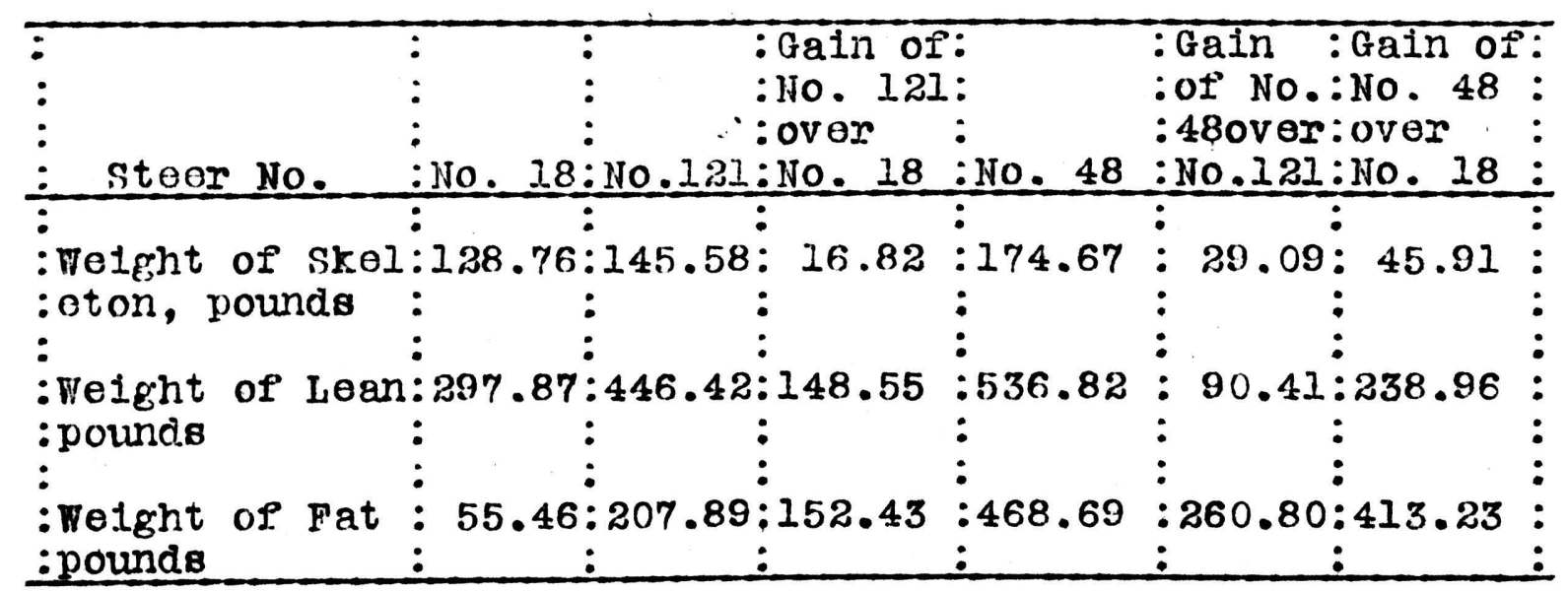

Since steer No. 121 galned over No. 18, 148.55 pounds of lean meat and 152.43 pounds of fat while he was gaining 16.82 pounds of skeleton; for every pound of skeleton gained there 

was a gain of 8.83 pounds of lean meat and 9.06 pounds gain In fat.

Similarly since No. 48 galned over No. 12l, 90.41 pounds of lean meat and 260.80 pounds of fat while he was gaining 29.09 pounds of skeleton; for overy pound of gain in skeleton, there was a gain of 3.11 pounds of lean meat and a gain of 8.97 pounds of fat, while the gain of No. 48 over No. 18, In lean meat was 238.96 and the fat 413.23 pounds. The skeleton had increased 45.91 pounds. Th1s means that for every pound gain in welght of bone No. 48 increased over No. 18, 5.20 pounds of lean and 9.00 pounds of fat.

This shows that up to the condition of No. 12l, the gain In lean and fat per pound of bone was very close together being 8.83 pounds and 9.06 pounds respectively. With steer No. 48 the Increase over No. 121 in lean, had dropped to almost a third of what it was in No. 121 while the fat was the same. W1th No. 48 the gain over No. 18 in lean per pound of bone had risen to over one-half and the fat remained the same.

The data shown in the foregoing tables demonstrates that a mature steor when recelving food beyond that required for malntenance uses the surplus for the growth of all parts of the body and for the storage of surplus fat. The skeleton growth 18 much less than the growth of muscle also less than the accumulation of fat. As the animal increases in fatness the relative amount of fat to lean increases. 

CHEMIOAL COMPOSITION.

Tables 9, 10, and 11 show the chemlcal composition of the parts of the steors 18,121 and 48 respootively. The weight of the out or organ is given in the first column and is followed by the percents of molsture, solids, ash, phosphorus, fat (ether soluble), nitrogen, and proteln. Tho protein is calculated from the nitrogen by multiplying it by the faotor 6.25 .

In steer No. 18 (table 9) the skeleton is found to contain the least water (29.3I per cent) of the parts analyzod with the exception of the kidney fat and offal fat. The kidney fat contains 10 per cent of molsture and 86.96 per cent of fat (other soluble matorial) In this antmal. It contains 2.63 per cont of protein and 0.12 per cent of ash with 0.02 per cent of phosphorus. The offal fat compares quite closely with the kidnoy fat.

The skeloton (contaluing only 29.31 per cent of molsture) 1s the highest in ash and phosphorus. The ash beling 24.59 por cent and the phosphorus 2.80 per cont. The ash and fat each represent about one-fourth of the welght of the skeleton.

The hide contalns more molsture than might be expected, belng 65.37 per cent. The ash and phosphorus are lower than we might expeot. The ash boing 0.87 per cent and the phosphorus 0.07 per cent. The nitrogen or protein 1s, on the other hand, the highest of any of the parts being 5.10 per cent nitrogon or 31.85 per cent proteld matter. 
STEER NO. 18. ANALYSIS OF THE.PARTS.

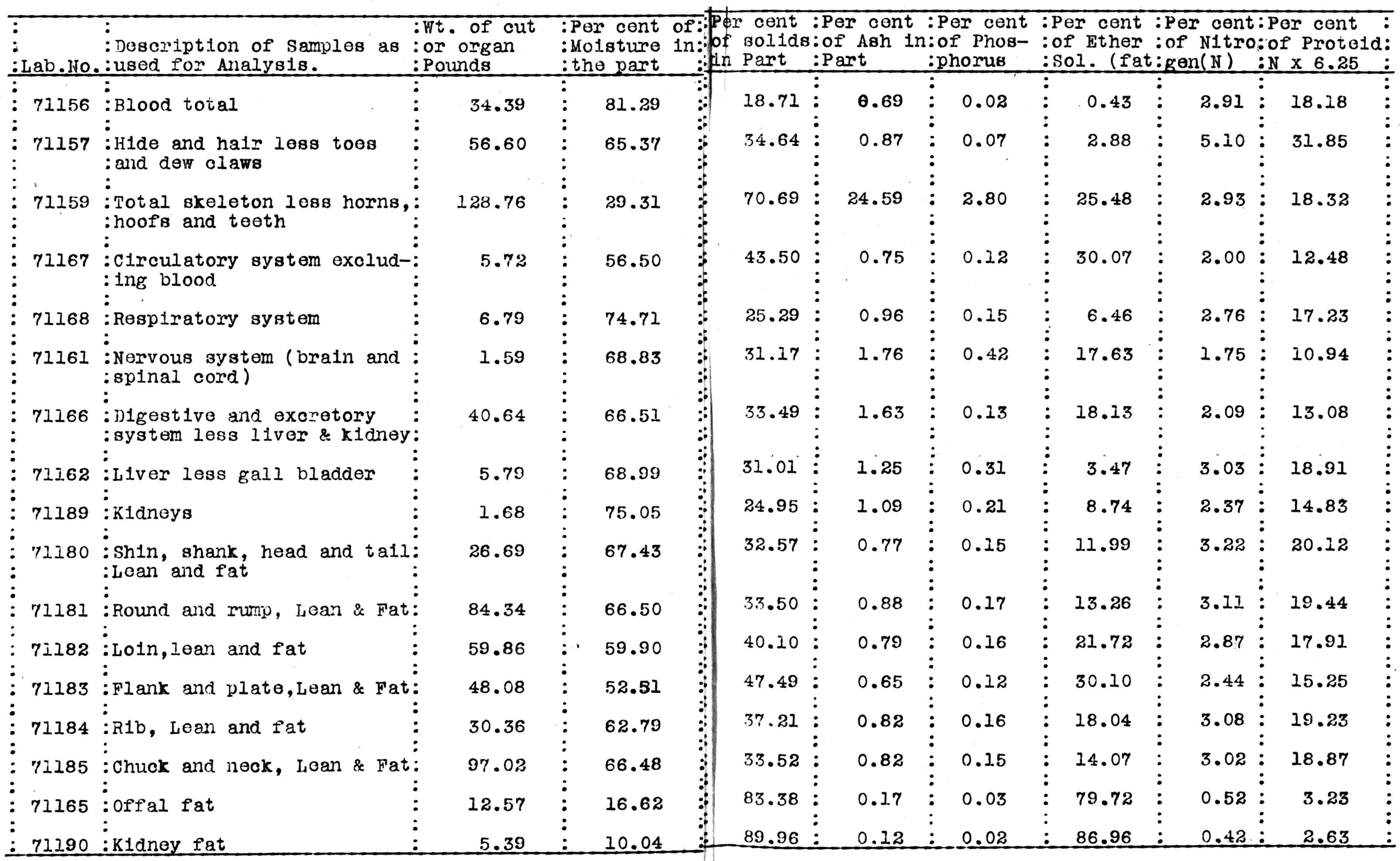


TABLE NO. 10.

STEER NO. 12I. COMPOSITION OF THE PARTS.

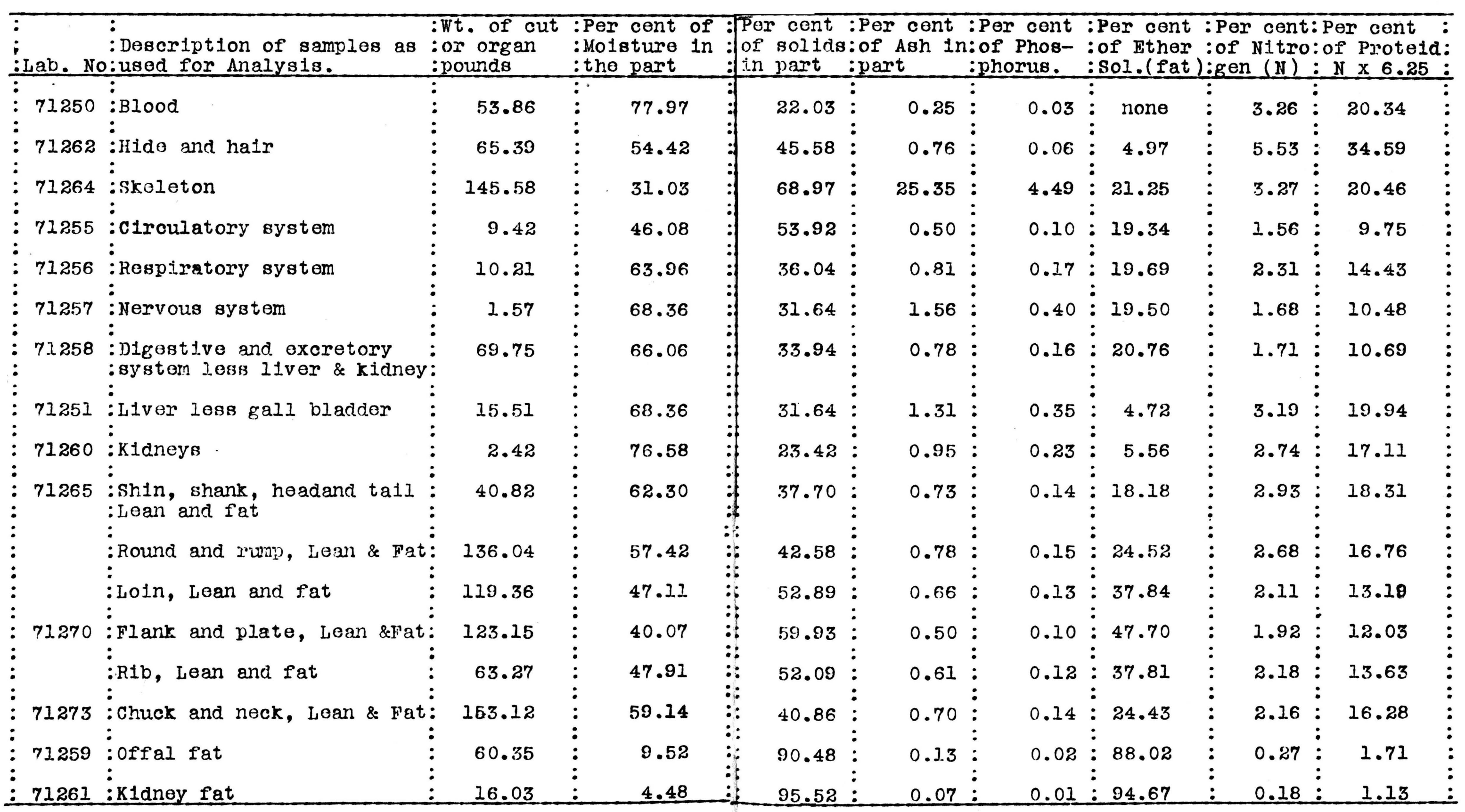


STEER NO. 48. COMPOSITION OF THE PARTS.

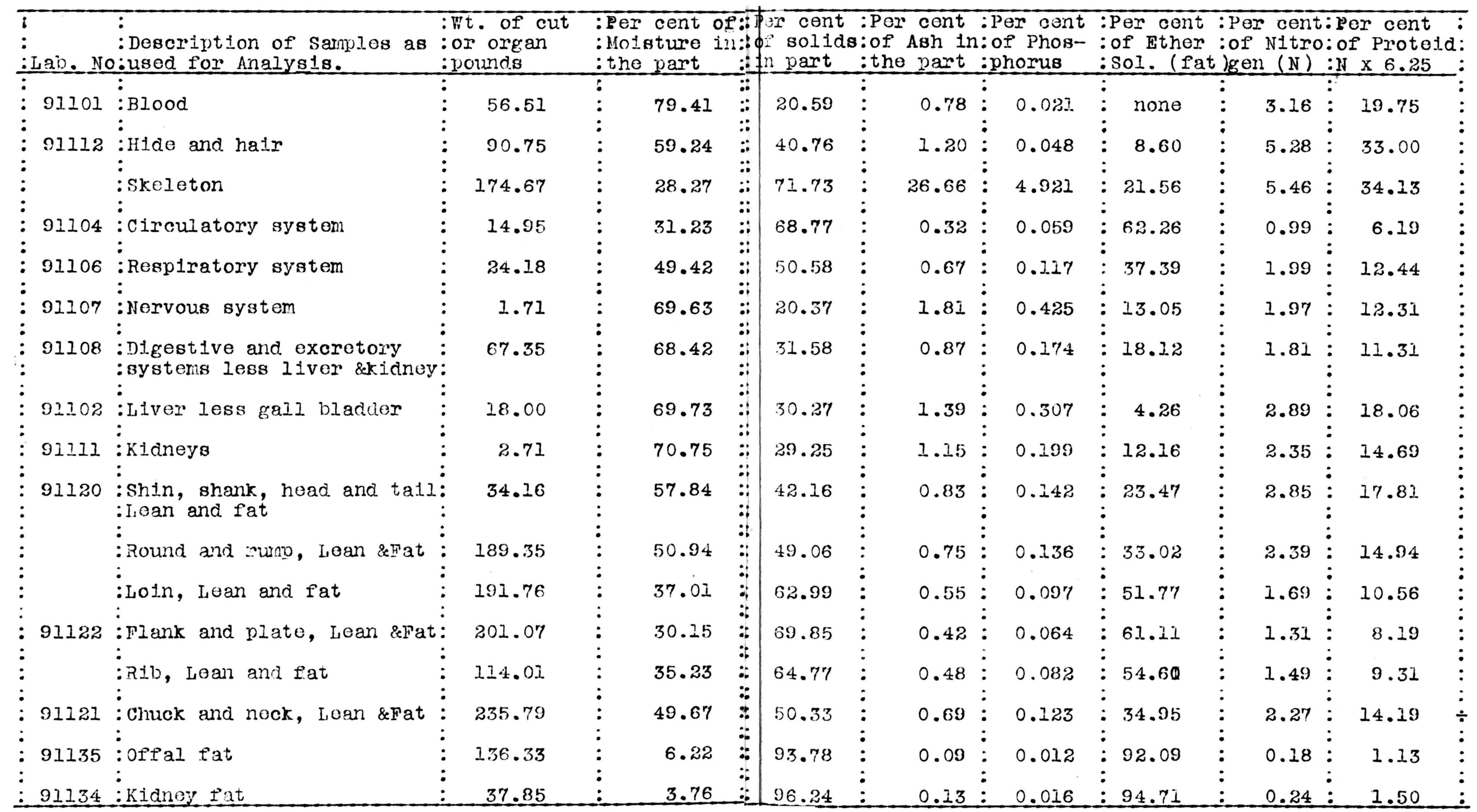



- The blood as would be expocted, contalns a high percentage of water being 81.29 per cent. It contains a goodly amount of nitrogenous matter it being 18.18 per cent protein.

The moisture in all parts excluding the blood, skeleton, offal fat and kidney fat 1 s betwoen 52 and 75 per cent of the wolght of the cut.

Turning to Table Ho. 10, It is found that as was the case with steer No. 18, No. 121 is found to be lowest in the per cent of molsture in the skeleton. Th1s was 31.03 per cent or Isightly ( 2 per cent) more than No. 18. The per cent of ash has increased with No. 121 about 0.8 per cent. The phosphorus content has increased quite a large anount being 1.69 per cent greator than with No. 18. The fat content has docreased about 4 per cent and the nitrogen increased about 0.34 por cent.

The skeleton of steer No. 48 shows a continued though small decrease in percentage of motsture content. The moisture, as was the case with the other two steers was least in the skeleton with the exception of the offal and kidney fats. The ash and phosphorus and nitrogen have all incroased in per cent. The fat is about the same as with No. I2I but still less than in No. 18.

The modsture content of the offal and kidney fat is considerably lower in steer No. 131 than in No. 18 and the ash, 

nitrogen and phosphoins sifghtly lower and the fat much more with No. 12l. Practically the same thing is noticed for No. 48. The fat being much purer in the fat animal than in the thin one. The molsture also decreases in amount. The hide contalns 54.42 per cent moisture vith No. 121 and 59.24 per cent with No. 48. Both 1ess than No. 18. The ash content of the hide has decreased with No. I2I and increased with No. 48. The phosphorus content of the hide has decreased about 0.01 per cent for both No. 121 and No. 48. The fat contont has risen perceptibly with each of the fatter steers and the protein has rematned about constant. The molsture in all parts in No. 121 excluding the blood, skeleton, offal and kldney fat is betweon 46 and 76 per cont. For No. 48 this anounts to between 30 and 70 per cent. In all parts with a very few exceptions, the molsture content has decreased appreclably between No. 121 and No. 18 and between No. 48 and No. 12l. It would seem that perhaps with the carcass cuts especially, the water may be roplaced with fat, for as the water decreased in the ratio of No. 18, to No. I2I to No. 48 , so the fat content of the parts increased in the same relation. The parts other than the carcass cuts were too varlable to show any relation.

several of the parts analyzed show that the ash content also decreasos with the fatter antmals but there are also several that show little change and ovon some gain is ash. 

1 The phosphorus content of each of the parts shows a condition similar to that of the ash. The per cent in most of the parts has decreasod with the fatter antmals. There are also several which show no change and perhaps a slight incroase.

The nitrogenous mattor in the parts also shows a general decline except perhaps the same exceptions noted above for the other eloments.

These rosults might tend to the conolusion that with the laying on of fat the molsturo, ash, phosphorus, and nitrogenaus matter 1s decreased. We can see a reason for this sinco fat 1s vory low in molsture, ash, phosphorus, and nitrogon, whon this fat is put on $1 t$ then increases the welont to such an extent that the composition of the parts are decroased appreciably in many cases regarding the moisturo, fat, phosphorus and nitrogen content. Again the ash, phosphorus and nitrogen show littlo if any change, whilo the molsturo goes dow and the fat rises.

The following tables have been calculated to show the relation of the moisture and the protein in the entire cut of lean and fat of the $: 1$ b of No. 48 and No. 121 and in the gain also In the lean meat of the stb of No. 48 and No. 121 and how this relation held with the gain in molsturo and protein of No. 48 over No. 12l. Similarly the data has been calculated for tho $r i b$ fat in the two antmals. In addition 

- Imilar results have been calculated for the solation betwoon the molsture and protein in the entire antral.

\begin{tabular}{|c|c|c|c|}
\hline$\circ$ & : Molsture grams & : Proteln grams & $\bullet$ \\
\hline No. $48 \mathrm{RIb}$ lean and fat: & 18058.83 & 4787.94 & \\
\hline :No. 121 " " $"$ " & 13748.44 & 3909.57 & \\
\hline No. 48 gain over No.121: & 4310.39 & 878.37 & \\
\hline No. 48 RIb lean & 13788.55 & 4060.36 & \\
\hline :NO. $121 "$ & 12952.15 & 3698.44 & \\
\hline :No. 48 gain over No.12l: & 836.40 & 361.92 & \\
\hline :No. 48 R1b fat & 4270.28 & 727.58 & \\
\hline$:$ No. $121 " n$ & 796.29 & 211.13 & \\
\hline :No. 48 gain over No.121: & 3473.99 & 516.45 & \\
\hline :No. 48 Entire body & 291233.00 & 105860.00 & \\
\hline$:$ No. 121 " & 239260.00 & 73935.00 & \\
\hline :No. $48 \mathrm{galn}$ over No.121: & 51973.00 & 31925.00 & \\
\hline
\end{tabular}

The following interpretation of this data is given:-

In No. 48 the ent1re rib cut (excluding bone) showed that for every gram of proteln present there was 3.77 grams of molsture in the cut.

In No. 121 the entire rib cut (excluding bone) showed that for every gram of protein present there was 3.52 grams of molsture in the cut.

The gain of No. 48 over No. 121 in the rib cut, composed of lean and fat, showed that for every gram of protein 

present there 183.40 grams of molsture in the lean.

With No. 121 it w1ll be noticed that in the lean of the rib cut, for every gram of proteln present there 183.50 grams of molsture in the lean.

The gain in the lean of No. 48 over No. 121 shows that for every gram of protein gained there $1 \mathrm{~s} 2.31$ grams of molsture gained. W1th No. 48 the fat of this $\mathrm{rlb}$ out shows that for every gram of proteln present there $1 \mathrm{~s} 5.87$ grams of molsture. With No. 121 the fat of the rib shows that for every gram of proteln present there 1s 3.77 grams of molsture. The gain In the fat of No. 48 over No. 121 shows that for every gram of proteln gained there $1 \mathrm{~s} 6.73$ grams of molsture gatned. With No. 48 for the ontire body the data shows that for every gram of protein present there 182.75 grams of molsture. With No. I2l for the entire body has for every gram of protoin, 3.21 grams of molsture.

The gain in protein and molsture for the entire body shows that for every gram of protein galned there is a gain of 1.63 grams of molsture.

The above data was studied to find out if possible, whether the molsture was replaced with fat.

The above data does not seom sufilcient to draw conclusions. Lawes and Gilbert in their interesting researches in the Rothamsted (England) station took up among other things a study of the fattening of the domestic animals. The exper1- 

ments were begun in 1848 and continued several years. The results were not published unt1l 1859. They undertook to find the ultimate composition of steers, sheep and pigs. The ent1re bodies of ten animals in each group wero subjected to analysis. A summary of their findings on beef animals is glven below:

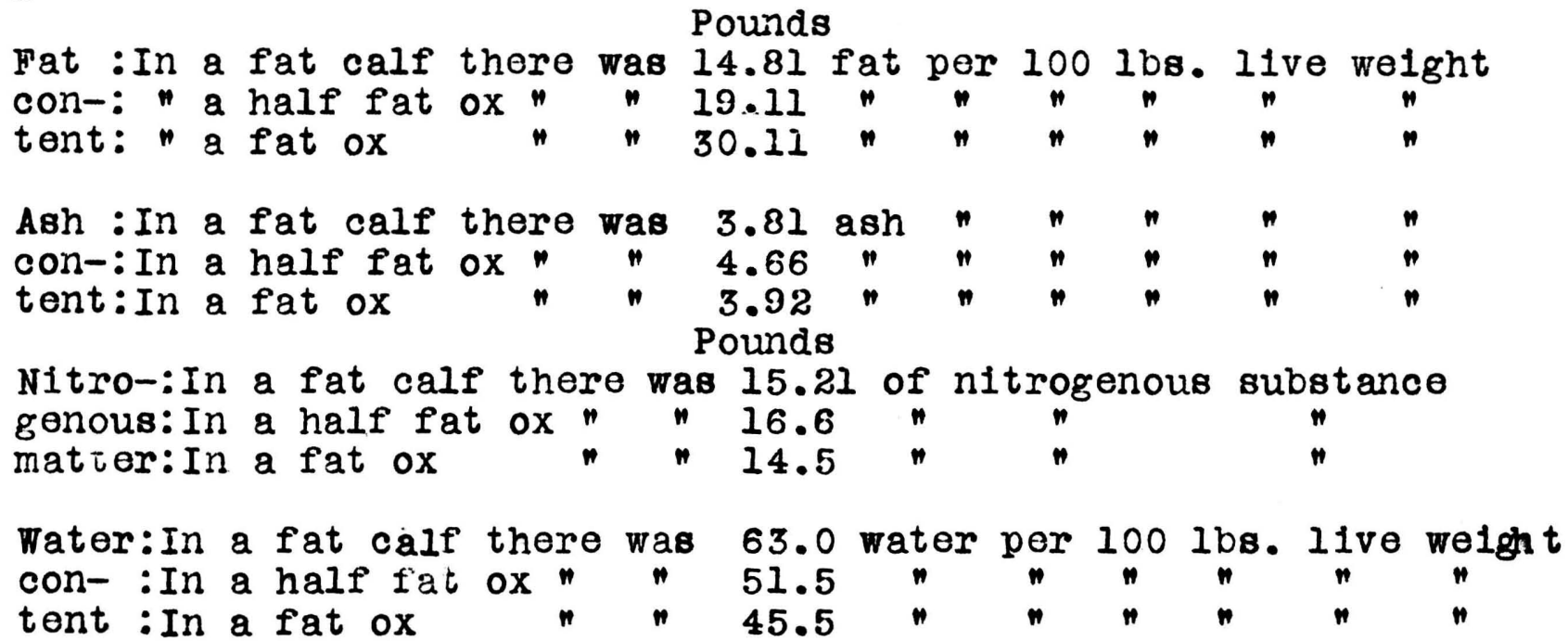

The composition of the bodies of the three steers Nos. 18, 12l, and 48 show results somewhat different from the above results of Lawes and Gilbert. The fat calf has no comparison with the data hereln presented, although steer No. 18, the thin emaclated one, compares in some respects with the fat calf of Lawes and Gilbert, in composition. Steer No. 121 might be called an animal similar to the half fat ox of Lawes and Gilbert's and steer No. 48 the fat ox but results do not warrant too close a comparison. The results obtained here, are given below. 

Per 100 Pounds live Weight.

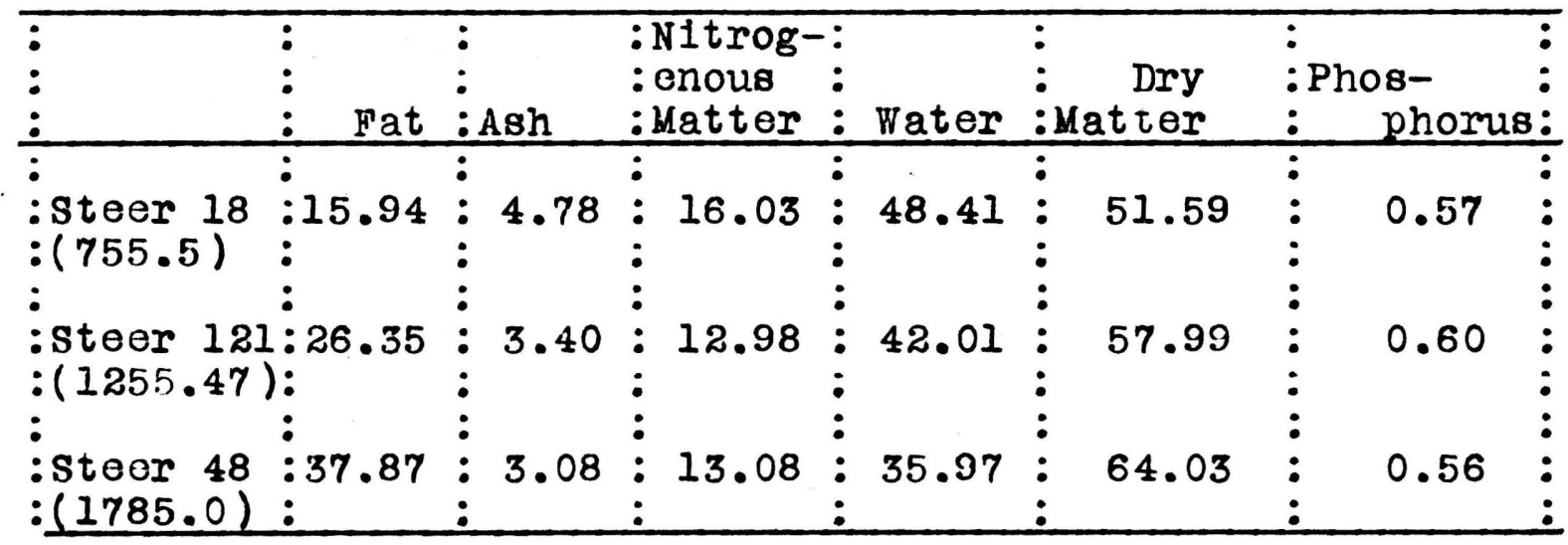

The fat content of the body is noticed to be higher in all three steers than Lawes and Gllbert showed for simllar animals. Steer No. 48 was apparently much fatter than their "Iat ox". The ash content shows a continual decline as the fattening process continues. Lawes and Gilbert showed that with the half fat ox the ash content was the highest. The nitrogenous part of the body 18 the nighest with the thin steer No. 18 and practically the same for No. 121 and No. 48. Lawes and G1lbert showed that it increased slightly with the half fat ox over the fat calf and decreased slightly for the fat ox.

The water content of the body 1 s greatest for the thin steer No. 18, showing less for the half fat steer No. 12l, and least for No. 48 the fat steer. Lawes and Gllbert showsd that the water content was the highest with the fat claf and lowest with the fat ox. However the steers analyzed by them showed a higher water content than those here. 

The phosphorus content of the bodles of the steers analyzed here is shown in the above summary table, but Lawes and Gilbert do not show any phosphorus in this connection. It is notlced that the phosphorus content is quite uniform through the fattening period.

Lawes and G1lbert state that there is more than two pounds of fat in the body of the fat ox, for each pound of nitrogenous matter or lean meat substance. It 1s found here that there is nearly three pounds of fat for one pound of nitrogenous matter. Th1s however was with the very fat steer No. 48. Steer No. 121 however, compares very closely with the above statement of Lawes and Gilbert showing that there 1s about one pound of nitrogenous substance for two pounds of fat. The thin animal No. 18 shows that the lean meat substance and the fat are about equally distributed, pound for pound.

It is evident that our fat animals were much fatter than thelr fat oxen, for they state that nearly half the body of the fat ox is water. It is found here to be considerably less than half. However, Lawes and Gllbert's results are the results of ten analyses and these here are only for one, of a definite fatness.

It is noticed that fattening is all the term implies; laying on of fat. During the fattening the total dry matter 1s much increased as the water content of the body decreases. 

The fat content increases much more than the nitrogenous matter. The relative percentage of the ary matter of the body increases about 6 or 7 per cent. Similarly the relative percentage of nitrogenous matter decreases about 2 or 3 per cent In fattening up to the condition of No. 121. The ash or mineral constituents in a like manner decrease one to one and a half per cent, while the fat increases ten to twelve per cent in the very fat steer. 

CONCLUSIONS.

1. The live welght increases during the process of fattenIng a steer.

2. The gain in live welght per day decreases the longer an animal is fed. The more feed consumed the less returns In meat pound for pound of gain. Therefore the most economical gains are not possible after a certain stage is reached in the process of fattening.

3. The hindquarter part of the carcass gains more in weight than the forequarter, the longer the antmal is fed.

4. The fat from pure fat storage places such as the kidneys stomach and Intestines, Increases very materially the longer an animal is fattened.

5. The fat 18 probably stored in those places for future use when lack of food supply necessitates a demand for such material by the animal body.

6. The relative per cent of the cuts in the body to the live welght decreases the longer the fattening process continues.

7. The ratio of lean meat in the carcass to the live weight decreases the longer an animal is fattened.

8. The rat1o of fat in the cuts of the carcass to the IIve welght increases the longer an animal is fed in the fattening process.

9. The ratio of bone in the carcass cuts to the I1ve welght also decreases as was the case with the lean meat. 

10. The bone of the animal carcass continued to grow at least in welght oven when the animal was nearly five years of age on a fattening ration.

11. With the exception of the offal and kidney fat, the skeleton contains the least amount of water of any of tho parts of the body analyzed. The relative percentage of the molsture decreases with the process of fattening.

12. The molsture content of the cuts decreases and the fat content increases with fattening.

13. The per cent of ash in the carcass decreases with fattening. The phosphorus content remaining apparently constant. The relative per cent of protein does not seem to Increase after the condition of No. 121.

14. A mature steer grows during the fattening process In practically all parts of the body.

15. A large part of the increase takes the form of fat but the ratio of all parts decreases the longer the fattening process continues. 







\section{$378.7 \mathrm{~m} 71$ \\ $\times 571$}


